IZA DP No. 3595

Scale, Diversity, and Determinants of Labour Migration in Europe

Anzelika Zaiceva

Klaus F. Zimmermann

J uly 2008 


\title{
Scale, Diversity, and Determinants of Labour Migration in Europe
}

\author{
Anzelika Zaiceva \\ IZA and University of Bologna \\ Klaus F. Zimmermann \\ IZA, Bonn University and DIW Berlin
}
Discussion Paper No. 3595
July 2008

IZA
P.O. Box 7240
53072 Bonn
Germany

Phone: +49-228-3894-0

Fax: +49-228-3894-180

E-mail: iza@iza.org

\begin{abstract}
Any opinions expressed here are those of the author(s) and not those of the institute. Research disseminated by IZA may include views on policy, but the institute itself takes no institutional policy positions.
\end{abstract}

The Institute for the Study of Labor (IZA) in Bonn is a local and virtual international research center and a place of communication between science, politics and business. IZA is an independent nonprofit company supported by Deutsche Post World Net. The center is associated with the University of Bonn and offers a stimulating research environment through its research networks, research support, and visitors and doctoral programs. IZA engages in (i) original and internationally competitive research in all fields of labor economics, (ii) development of policy concepts, and (iii) dissemination of research results and concepts to the interested public.

IZA Discussion Papers often represent preliminary work and are circulated to encourage discussion. Citation of such a paper should account for its provisional character. A revised version may be available directly from the author. 
IZA Discussion Paper No. 3595

July 2008

\begin{abstract}
Scale, Diversity, and Determinants of Labour Migration in Europe*

While global migration is increasing, have only increased slowly. This paper contributes to a better understanding of the determinants and scale of European migration. It surveys previous historical experiences and empirical findings including the recent Eastern enlargements. The determinants of migration before and after the 2004 enlargement and in the EU15 and EU10 countries are analysed using individual data on migration intentions. In addition, perceptions about the size of migration after the enlargement are studied. The potential emigrant from both old and new EU member states tends to be young, better educated and to live in larger cities. People from the EU10 with children are less likely to move after enlargement in comparison to those without family. There exists a correlation between individual perceptions about the scale of migration and actual flows. Better educated and left-oriented individuals in the EU15 are less likely to perceive these flows as important.
\end{abstract}

JEL Classification: F22, J15, J61

Keywords: migration, EU Eastern enlargement, migration intentions, determinants of labour migration

Corresponding author:

Klaus F. Zimmermann

IZA

P.O. Box 7240

53072 Bonn

Germany

E-mail: Zimmermann@iza.org

\footnotetext{
* We thank Ira Gang, Mary Gregory, Douglas Krupka, Steve Nickell, Michael Shields, and an anonymous referee for very useful comments on an earlier draft.
} 


\section{INTRODUCTION}

Globalization and the recent Eastern enlargements of the European Union (EU) highlight the importance of migration-related issues in Europe, which is one of the main migration destinations in the world. In spite of substantial mobility barriers, immigration into the EU is large and dominates internal mobility, which is traditionally low. Less than $2 \%$ of EU working age citizens live in another EU member state, the majority originating from the old EU15 (European Commission, 2006b). Labour migration from EU and non-EU countries has been a dominant feature of post World War II European migration, although it was only explicitly promoted during the 1960s and later by the EU enlargement and market integration policies. Over the last decade, one of the key questions that have attracted attention from scientists and policy-makers is immigration from Eastern Europe. Lay concerns about whether immigrants may depress wages, cause unemployment, exploit social security systems and generate social tensions have been contrasted with scientific emphasis on the economic needs of skilled workers by native firms and the creative potentials immigrants might carry with them.

In general, the economic impact of immigration on receiving labour markets depends on the scale of the immigration flows, the composition of the migrating population and the functioning of the receiving economy. How large has internal migration been in the EU15, the "old" European Union? Has and will mobility change after the 2004 enlargement with the admission of the EU10, the "new" member states? What drives migration in Europe and who were the potential migrants in the old and the new EU members before and after the enlargement? How is post-enlargement migration perceived by individuals in the EU25? These are the questions that we deal with in this paper.

The rest of the paper is organised as follows. Section II outlines the historical and conceptual background of European labour migration. Section III introduces the literature on EU Eastern enlargement. Section IV presents an empirical investigation on the determinants of migration intentions in the EU25 before and after enlargement. Section V analyses the perceptions on the scale of migration in the EU25 after enlargement. Section VI concludes and provides policy implications.

\section{EUROPEAN LABOUR MIGRATION BEFORE EASTERN ENLARGEMENT}

\section{a. Historical background}

After World War II Western Europe became one of the main immigration regions of the world. Brücker et al. (2002), Bonifazi and Strozza (2001), Fassmann and Münz (1994), Jennissen et al. (2006), Zimmermann (1995b, 2005b), Tranaes and Zimmermann (2004) and Zimmermann et al. (2007) document the scale of migration and developments of migration policies in Europe. While the immigation issue is nothing new in many parts of Europe, non-EU migration has largely dominated internal EU migration. Migratory flows between EU countries are low. Only $0.1 \%$ of the EU15 nationals move from one member state to another every year, although regional mobility within countries is significantly higher (European Commission, 2006b). Bonin et al. (2008) report that internal mobility within EU countries between 2000 and 2005 has been 1\%, while it was 2\% in Australia and 3\% in the United States.

Several phases of European migration history can be distinguished. The first period of postwar adjustment and decolonisation covering the years between 1945 and up to the early 1960s was a period of pure supply-driven migration. Germany experienced a strong inflow of people displaced by the war. The United Kingdom, France, Belgium and the Netherlands were affected by return migration from European colonies and the inflow of workers from the former overseas territories. In the United Kingdom, for instance, the immigrants came from the newly independent Commonwealth countries, beginning with the Caribbean countries and continuing with people from the Indian subcontinent. 
The second phase of labour migration lasted until the first oil price crisis in 1973/74, and was motivated by the very strong economic growth at the time. The resulting labour shortages in the second half of the 1950s and the 1960s induced a number of Western European countries to open up for immigration. Germany, Austria, Belgium, the Netherlands, Switzerland, Denmark and Sweden actively recruited unskilled workers from the Southern European countries in a temporary scheme (established as guestworker system) which became permanent in many cases. Return migrants to Belgium, the Netherlands, the United Kingdom and France were also permanent, since they were the consequence of decolonisation.

Restrained migration was the third phase of post-war migration into Europe, where in the face of increased social tensions and fears about a recession after the first oil price shock, active labour recruitment was stopped from 1973 onwards. In spite of the fact that the guest-worker system was installed to foster temporary migration, return migration was sluggish. To the contrary, family reunification and humanitarian immigration went on. In sum, immigration from non-EU countries continued while net immigration from EU countries became low.

East-West migration and asylum seekers and refugees became the main channels in the fourth phase of the new immigration starting at the end of the 1980s. Ethnic Germans migrating to Germany played a substantial part in this. Whereas in the 1970s and 1980s, asylum seekers originated mainly from Asia and Africa, the inflow of asylum seekers and refugees from European countries increased significantly in the 1990s, originating in the dissolution of the political regimes in the former socialist states in Eastern Europe. The wars in Croatia, Bosnia-Herzegovina and Kosovo caused a migration surge from these regions that followed established ethnic networks. Also the clashes between Turks and Kurds in the South-East of Turkey generated a substantial number of additional refugees. However, migration flows from the East have been fairly small and stabilized soon.

Around 1992 some European countries, especially Germany, became more restrictive towards the immigration of asylum seekers and refugees. While most European countries did not further restrict their refugee and asylum policies, Europe remained in practice largely closed for economic and non-economic migration resulting in the fifth phase of Fortress Europe. However, there are a number of notable exceptions including the United Kingdom, which received about a half million of immigrants from traditional source countries in the 1990s, but also Italy, Greece and Spain who became immigration countries. A substantial rise in perceived illegal immigration amends this picture. In recent years, the EU Commission has recognised the importance of skilled immigration from non-EU countries, but has so far failed to convince the member states of the need to establish a common European economic immigration policy. The United Kingdom is one of the EU countries that already executes a policy to attract such migrants from the new Eastern member states and non-EU countries under its Managed Migration policies and Highly Skilled Migrant Programme (Ruhs and Martin, 2008; Ruhs, 2007).

\section{b. The migration decision}

The core analytical framework of the migration decision goes back to the human capital model of Sjaastad (1962) and Becker (1964). Theories and reviews of the migration decision can be found, for example, in Borjas (1999), Chiswick (1999), Greenwood, (1997) and Bauer and Zimmermann, (1999). According to some theories, migration flows respond largely to expected differences in regional disparities in prosperity (Harris and Todaro, 1970). Hence, differences in earnings, unemployment rates, costs of living, public goods and public transfers are also important determinants of a move. The decision to move is affected by the costs of moving that not only include monetary costs like travel expenses and foregone earnings, but also psychological costs arising from the separation from family and friends. The likelihood of migration should decrease with age, reflecting the smaller expected lifetime gain from moving for older people. Individuals with higher education should exhibit a higher migration probability, because higher education reduces the risks of migration through a higher ability to collect and process information. The risks 
and costs of movements are expected to rise with distance, because information about labour market conditions is expected to be better for closer locations. Family issues also typically play an important role (Mincer, 1978). Most migrants move within the context of ethnic networks, resulting in the formation of ethnic clusters in the host country (Massey, 1990). The mere existence of network and chain migration significantly alleviates the risks and costs and accelerates movement. Ethnic networks provide migrants with valuable information about jobs and access to local labour markets. Overall, migrants may be positively or negatively self-selected with respect to their characteristics (Borjas, 1987, Chiswick, 1999). The Roy model applied by Borjas (1987) also suggests that relative inequality matters and qualified migrants move from more (less) equal source countries to less (more) equal host countries. Consequently, countries with higher equality (and a lower Gini coefficient) should have higher emigration rates.

In practice, Europeans have proven to be fairly immobile (see Zimmermann, 1995a, 2005a, 2005b and Bonin et. al, 2008, for further references and insights). Barriers which have been deemed as responsible for low European mobility rates include a number of micro and macro factors such as the rise of dual-earner households (joint mobility decisions being more difficult for such households), the rise in homeownership, the limited portability of social security entitlements, lack of recognition of foreign qualifications, the lack of innovation dynamics in the EU resulting in fewer job opportunities, the lack of jobs due to poor economic growth, the ageing of the working population, and poor EU-wide information flows about job markets. Ambiguous effects of new commuting perspectives through faster trains and cheaper airlines may stimulate or prevent migration decisions. For instance, lower transportation costs might stimulate commuting to a job, but lower the likelihood for a residential move. It may also encourage more regional job mobility than stimulate international migration by providing an easier access to a larger local labour market.

Mass unemployment has its own way of creating immobility: Jobless migrants rely stronger on local social networks than natives to keep in contact with society and to reintegrate in the labour market, which keeps mobility incentives low. Migration is also low because there are too many low-skilled and too few high-skilled individuals in the labour force with too few job offers for the former and too few workers from the latter job category. Regional mobility is also moderated by wage compression at the national levels. However, language and cultural differences are seen as the most problematic barriers of geographical mobility in Europe. Multicultural identities that could foster labour market integration (see Constant, Gataullina and Zimmermann, 2006, and Constant and Zimmermann, 2008) are not sufficiently developed.

\section{c. European mobility at work}

It is difficult to study mobility in Europe. First, geographic mobility is low and difficult to observe. Second, international migration cannot be measured by country surveys which only capture individuals before or after migration. Transnational surveys are missing. Third, migrants are not followed across countries, so that repeat, circular and chain migration cannot be studied. Fourth, the definition of a migrant is not always clear. Official statistics may treat foreign nationals as migrants, ignoring naturalized individuals but including second generation immigrants who kept the citizenship of the country of origin. Finally, no updated and consistently gathered data sets are maintained which are sufficiently appropriate for examination of labour migration. Measuring migration intentions is a valuable step ahead, although these measures may overestimate the scale of mobility and focus only on the supply side (Boeri et. al., 2002). They still provide very valuable information on the characteristics of potential migrants. We will discuss the value of intention measures further in section IV. Most recent studies of migration intentions were undertaken in the context of EU enlargement. (See also Bauer and Zimmermann, 1997, 1998 for early investigations of the labour market implications of EU East enlargements.)

The characterisation of migrants is severely handicapped by data limitations, involving both the definition of what is to be measured (foreign-born, foreign nationality) and the location and recording of those to be counted. The United Nations (UN), the International Labour Office (ILO), 
the Organisation for Economic Co-operation and Development (OECD) and the European Statistical Office (Eurostat) all provide relevant measures, but typically with conflicting definitions and incomplete recording. Tables 1 and 2 attempt to capture the best picture relevant to the purpose under investigation in this paper making use of Eurostat and OECD data sources and from the EU Labour Force Surveys (LFS). Migrants can be defined or classified as individuals born outside of the country (foreign-born), people with a foreign nationality, persons who have a migratory background (parents were foreign-born) or migrants with a particular duration of residence. Obviously, there are foreign-born natives, foreign citizens born in the host country, foreign-born foreigners who have taken the citizenship of the host country and individuals with double citizenships. This suggests that the measurement of migration can be difficult.

Table 1 provides information on the level and trends of migration measured by the share of migrants in the total population of the receiving countries for the EU27. It documents the migration stock from two different data sources (Eurostat and OECD), for two years and two definitions (citizenship and foreign-born). This table has to be interpreted with caution, since reporting procedures differ across countries and sources and for many countries data is missing. ${ }^{1}$ Although providing an incomplete picture of European migration and confirming a poor state of migration statistics, this table suggests several interesting facts.

The size of migration is rising for the EU15, while it is stagnant for the EU12, the new member states. If anything, the standard deviation is rising for the old EU and falling for the EU12. Cyprus, United Kingdom, Spain, Portugal, Italy and Ireland have all seen substantial increases of the foreigner share in the total population over the period of 2000 to 2006. The rise in the share of foreign-born is substantial for most of the countries (mainly from the EU15), for which the data is available, perhaps with the exceptions of Sweden, Luxembourg and Germany. There are typically more foreign-born in the country than foreign nationals with the exception of Luxembourg. There exist differences in the relative shares of foreign nationals between the OECD and Eurostat data for Greece, Ireland and Spain in 2006/2005, but only for Greece in 2000/1999.

Table 2 shows numbers from the 2006 EU Labour Force Survey for the share of foreign citizens and foreign-born differentiating between EU and non-EU region of origin. The results are broadly consistent with the findings in Table 1, although there exist several differences. Among the foreign national shares, Luxembourg and Belgium rank first for other EU nationals, while Ireland and Austria are first for the non-EU foreigners. Among the other EU foreign-born, again Luxembourg and Belgium clearly dominate. However, among the non-EU foreign-born, the picture is more equal: Sweden and Austria are ahead followed by France, the United Kingdom, Belgium, and the Netherlands.

\section{EASTERN ENLARGEMENT OF THE EU}

\section{a. The background}

In May 2004, Cyprus, the Czech Republic, Estonia, Hungary, Latvia, Lithuania, Malta, Poland, Slovakia and Slovenia joined the European Union, followed by Bulgaria and Romania in January 2007. These enlargements were unprecedented: income differentials between the Central and Eastern European countries (CEEC) and EU15 were large, unemployment was high, migration from these countries was restricted, and they had undergone a transition from socialist to market economies. Potentially, there were strong economic incentives in the CEEC to migrate.

Due to the concerns about negative effects on the labour markets and "welfare tourism" transitional periods of up to seven years were imposed for workers from the new member states with the exception of Malta and Cyprus. These transitional arrangements are based on a so-called " $2+3+2$ " formula, and had to be reviewed two years after the enlargements, and again three years

\footnotetext{
${ }^{1}$ We have compared figures from Eurostat online database for 2000 (column 1) with those in Eurostat Population Statistics (2006). With several exceptions, the figures were largely similar.
} 
later. A final two-year phase of restrictions is permitted only in cases of serious disturbances in countries' labour markets. Only the United Kingdom, Ireland and Sweden have opened up their labour markets immediately in 2004. The United Kingdom, however, adopted a mandatory Worker's Registration Scheme (WRS), under which workers coming from the EU8 countries had to register with the Home Office. Following the review based on the EU Commission's Report (2006), seven more member states have decided to lift restrictions in 2006 and 2007 (Spain, Finland, Greece, Portugal, Italy, the Netherlands, Luxembourg) while others have simplified their procedures (Belgium, France, Denmark, Germany). As for Bulgaria and Romania, ten EU25 member states (Czech Republic, Estonia, Cyprus, Latvia, Lithuania, Poland, Slovenia, Slovakia, Finland and Sweden) have liberalized access to their labour markets, while the rest have decided to maintain the restrictions.

How large was the scale of migration before and after the enlargement? It is difficult to provide a comprehensive picture as the statistical data are still very preliminary and often not available. Figure 1 shows net immigration rates (net flows divided by the population of the receiving country) for the EU15 member states with available data from the Eurostat online database. It suggests that there was an increase in immigration from the new member states in most of the countries, for which the data is available. However, in many cases the size of this increase was small. In the United Kingdom the gross data suggests that the increase was relatively large. In Sweden there is a larger increase in net migration in 2006. While in the majority of these countries Poland is the main sending country, it is Estonia for Finland and Romania for Spain. This suggests that geography, language, country size and networks matter.

Unfortunately, there are no Eurostat data available for Ireland, in which the increase has been large. Blanchflower et al. (2007) and Ruhs (2007) have recently documented the inflow for the United Kingdom and Hughes (2007) for Ireland. Measured by the Personal Public Service Numbers (PPSN) that Ireland issues to EU10 nationals, there were about 54,000 immigrants in MayDecember 2004, 112,000 in 2005, and 139,000 in 2006. For the United Kingdom, the most recent Accession Monitoring Report (Home Office, 2008) provides statistics on the policy of the British government to regulate inflows and to restrict access to benefits. According to this report, the number of applicants to the WRS has risen from 134,550 in May-December 2004 to 234,725 in 2006 and fallen slightly to 217,740 in 2007 (see Figure 2). The majority of applicants are from Poland. However, both Irish and British measures capture only gross inflows and are likely to overstate the long-term permanent immigration, since much of it is of temporary nature. For example, in March 2008 in the United Kingdom 60\% of applicants intended to stay for less than three months (Home Office, 2008).

\section{b. Review of selected studies on potential and actual migration}

Since 1990, several studies have attempted to predict future migration flows from the new member states. (For surveys see, among others, Alvarez-Plata et al., 2003; Boeri and Brücker, 2005; Zaiceva and Zimmermann, 2008.) It is difficult to compare the results of these studies since they vary in methodology and in the range of variables included in the model. Nevertheless, in spite of large heterogeneity, most of them find that between $2 \%$ and $4 \%$ of the population of the Central and Eastern European countries will move to the West in the long run, which would constitute about 1\% of the EU15 population.

The current literature can be divided into two broad groups: (i) predictions based on the intentions to move to the West using surveys, and (ii) extrapolations or forecasts based on historical data for countries other than the new member states. The main advantages of the former methodology include availability of individual characteristics, and the possibility to distinguish between short- and medium-term migration (and commuting). However, it is difficult to determine how close the intentions are to actual realizations (see Section IV). In general, the migration potential in these studies ranges between 1\% and 4\% of the 2004 accession countries' population, and it is higher for nationals from Bulgaria and Romania (see, for example, Fassmann and 
Hintermann, 1997, Krieger, 2004). Wallace (1998) reports higher numbers (7\%-14\%), and also shows that one of the most preferred options of geographic mobility is cross-border commuting. It is the young, well-educated, and those without family who are more willing to emigrate.

Extrapolations or forecasts based on historical data arrive at several conclusions regarding the migration scale (see, for example, Layard et al., 1992; Franzmeyer and Brücker, 1997; Bauer and Zimmermann, 1999; Hille and Straubhaar, 2001; Sinn et al., 2001; Fertig and Schmidt, 2001; Dustmann et al., 2003; Alvarez-Plata et al., 2003; Boeri and Brücker, 2005; Zaiceva, 2006). Based on econometric estimates from historical experiences with EU Southern enlargement for the periods of restricted and free mobility, Bauer and Zimmermann (1999) simulate potential migration to range from $\mathbf{0 . 1 5 \%}$ in Slovenia to $6.54 \%$ in Romania. Unsurprisingly, potential migration is higher in a "free mobility" scenario, where simulations are based on estimates from the period with unrestricted mobility. Boeri and Brücker (2001) find that under the free mobility assumption, 3.5\% of the Central and Eastern European population will move to the EU15 by 2030. Alvarez-Plata et al. (2003), an update of Boeri and Brücker (2001), estimate a slightly lower migration potential. They also find that transitional periods tend to postpone migration, but have only a marginal impact. Note that such projections are subject to many problems related to the strong assumptions imposed.

Several recent studies have evaluated the actual migration after the enlargement. According to the EU Commission's Report (2006), the overall increase in immigration after 2004 was rather limited and was attributable mainly to the increases in Austria, Ireland and the United Kingdom. It also suggests that there is no conclusive evidence on a direct link between the scale of migration and the transitional arrangements. Gilpin et al. (2006) report that in the United Kingdom, the number of nationals from the new member states increased substantially, but do not find a statistically significant link between increased immigration and the rise in the United Kingdom claimant unemployment. Blanchflower et al. (2007) show that the propensity to migrate is correlated with income per capita, unemployment rates and life satisfaction in the new member states and also find no negative impact on the British economy. Ruhs (2007) discusses the migration policy context of opening up the borders and argues that there is a need for stronger enforcement of labour laws and regulations aimed at immigrants from the new member states. Doyle et al. (2006) document a small increase in immigration from the new member states in Sweden. Wadensjö (2007) provides updated figures. There is a remarkable increase in the number of foreigners in Ireland between 2003 and 2005, and the majority of this flow in 2005 consisted of nationals from the new member states. The authors also argue that the immigration to Ireland is primarily demand-driven and does not generate displacement effects on the aggregate level.

All these studies report that the majority of migrants are male, young, come from Poland and the Baltic states, have relatively high or medium skill levels and are concentrated in low-skilled sectors. No evidence of "welfare tourism" was found. Indeed, our own analysis using the British Labour Force Survey (see Table A6) shows that the proportion of recent immigrants from the EU10 countries claiming benefits in the United Kingdom is the same as from the EU15 countries, and childcare benefits account for more than $70 \%$ of the benefits taken up by East European. Finally, Brenke and Zimmermann (2007) document an increase in net immigration flows from the new member states into Germany despite the "closed door" policy. The authors show that females constitute the majority of these immigrants, and that these immigrants are underrepresented in highly qualified jobs despite high qualifications, that they exhibit a lower employment rate than natives and show that self-employment was used as a possible channel of entry to Germany.

Would immigration have increased as significantly in Ireland and the United Kingdom in the absence of the diverse transitional arrangements? It is likely that a "migration diversion" has occurred into the countries that have opened up their labour markets early (Boeri and Brücker, 2005). Otherwise, network effects and geographical closeness would have attracted many more migrants to Austria and Germany than actually went. However, other factors may have also contributed to the unexpectedly strong rise of Eastern immigrants: Many immigrants have studied English at home or would like to study it in these countries (Anderson et al., 2006). Enlargement 
may have contributed to the legalization of previously illegal immigrants, which would imply a pure statistical effect. Finally, a demand-driven immigration in the case of Ireland was likely to occur in any case to fill in the available vacancies.

\section{DETERMINANTS OF MIGRATION INTENTIONS IN EU25 BEFORE AND AFTER ENLARGEMENT}

The studies surveyed above suggest that migrants in Europe possess certain individual characteristics which distinguish them from non-migrants. In the absence of longitudinal crosscountry migration data, intentions to move provide a potential to identify and investigate these differences. Such an analysis typically assumes that intentions are a monotonic function of the underlying variables that determine actual migration behaviour. Obviously, there exists a gap between migration intentions and their realizations that will be the larger the larger the barriers are to enter the host countries and the less information is available about the host countries' labour markets and policies.

We follow here a broad strand of literature that analyses migration intentions in different countries including, for example, Burda (1993) for Germany, Ahn et al., (1999) for Spain, Epstein and Gang (2006) for Hungary, Fidrmuc and Huber,(2007) for the Czech Republic, Liebig and Sousa-Poza (2004) for 23 countries, Drinkwater, (2003) for Central and Eastern European countries, Krieger (2004) for accession countries, Fouarge and Ester (2007a, 2007b) and Bonin et al. (2008) for the EU25. This literature relies on a high correlation between migration intentions and their realisations.

In socio-psychological theory actions depend on the intentions to perform them, which in turn are functions of attitudes towards that behaviour and the perceived subjective norms about performing that behaviour (Fishbein and Ajzen, 1975, Ajzen, 1988). Thus, intentions data provide very valuable information, but are only imperfectly correlated with future behaviour and have to be treated with caution (Manski, 1990, Bertrand and Mullainathan, 2001).

Several studies confirm that migration intentions are indeed closely related to the subsequent move. Gordon and Molho (1995) find that around 90\% of British respondents who expressed an intention to migrate, did move within five years. Böheim and Taylor (2002) using panel data for Britain show that those who expressed a preference for moving experience three times higher probability of moving. Dustmann (2003) using panel data for Germany reports that of those immigrants who returned to their countries of origin from Germany during 1984-1997, 84\% indicated in 1984 that they have the intention to return.

A different approach is undertaken in Blanchflower et al. (2007). The authors analyse the characteristics of immigrants from the new EU member states in the United Kingdom and find that they are "highly consistent" with the individual determinants of the intentions to move to another European country from the Central and Eastern Eurobarometer 2002 data. They argue that "intentions appear to be highly correlated with subsequent actions" (p. 13). Examining the characteristics of pre- and post-enlargement migrants for the United Kingdom using the Eurobarometer data and the British Labour Force Survey (see Table A6) shows that they are indeed largely in line with the determinants of migration intentions presented in this section.

There exist several additional reasons why using intentions data is valuable. First, migrants may be positively or negatively selected. Analyzing determinants of potential migration in the sending countries may mitigate some of the selection problems, which are present in host country data due to selective immigration policy, geographic proximity and historical links (Liebig and Sousa-Poza, 2004). Second, understanding determinants of migration intentions may help designing effective targeted migration policies (Fouarge and Ester, 2007b). Finally, if anything migration intentions data are expected to overestimate the magnitude of potential emigration. Here, however, 
we are interested in the identification of the determinants of the migration decision that are probably less biased.

Several studies have analysed migration intentions from different Central and Eastern European countries. For example, Krieger (2004) presents several tabulations of individual characteristics in order to identify potential migrants from this region in 2002. Recent work by Fouarge and Ester (2007a, b) characterise migration intentions for the old and new EU member states for 2001, 2002 and 2005 and analyse their determinants in 2005. The novel feature here is that we focus on the determinants of migration intentions before and after the enlargement and analyse their changes in EU10 and EU15 countries.

We use the 2001, 2002 and 2005 waves of the Eurobarometer data and focus on the question regarding migration intentions in the next five years. (See Appendix for the exact wording of these questions.) The dependent variable equals 1 if the respondent answers that she intends to move within the same city or region, equals 2 if she intends to move to another region within the country and equals 3 if she intends to move abroad. ${ }^{2}$ We need to combine EU and non-EU destinations into one, since the number of respondents with inclinations to move to a non-EU country is negligible. In the descriptive analysis, however, we differentiate between these two destinations. Intending to focus on labour migration, we drop pensioners and students, and keep individuals between 18 and 64 years old with non-missing information on the key explanatory variables.

Figure 3 reports percentages of individuals with intentions to move to another EU country and to a non-EU country before and after enlargement. It shows that emigration intentions in 2005 in the EU10 are on average higher than in EU15, and they are on average lower in 2002. There are also differences in the preferred destinations: while in 2005, 2.4\% of the respondents in EU15 reported another EU country as a preferred destination, the corresponding number for EU10 was around $4 \%$, and the proportions were similar before the enlargement. On the other hand, the proportion of those willing to emigrate to a non-EU country is larger in the EU15 than in the EU10 both before and after enlargement.

We expect young individuals to express a higher willingness to migrate, since the time to reap the expected returns from migration is longer for them. More educated individuals are also expected to have larger moving intentions, since they probably face lower costs of migration and job search. On the other hand, married individuals and those with children are expected to have lower willingness to migrate because of the psychic costs of separating from their family. Home owners are expected to have lower migration intentions, because of their greater attachment to the region and since they may face the additional costs of selling their property. Regarding labour market status, unemployed individuals may be more willing to look for a job abroad. However, they may also be attached stronger to social networks and experience liquidity constraints that could preclude them from moving. Previous migration experience is expected to stimulate migration via lower information uncertainties and established migration networks. In addition, migration may also lead to the increased marital instability that in turn would lead to more migration (Mincer, 1978).

Table 3 (see also Tables A2 and A3 covering the complete estimation process) shows marginal effects from the multinomial logit regressions for the moving abroad outcome relative to those not willing to move anywhere. Let us first focus on the EU10 and compare the determinants before and after the enlargement. The results are consistent with the human capital migration theory. In general, the impact of individual characteristics is stronger after enlargement. ${ }^{3}$ Older individuals and those living in rural areas and small towns are less willing to emigrate. Potential

\footnotetext{
${ }^{2}$ Note that in principle multiple answers are possible. Following Fouarge and Ester (2007a) we generate this variable according to the longest intended move.

3 In a pooled model for 2002 and 2005 for the EU10, a 2005 dummy was positive and significant confirming higher immigration intentions after the enlargements. However, its interactions with education and children dummies were not significant. Note also that these are pooled cross-sectional data, and the results may be due to the change in the composition of the sample.
} 
migrants are positively selected with respect to education and the positive impact of human capital is larger after the enlargement. Previous migration experience also matters. With the exception of the inactivity status, labour market status variables are insignificant both before and after enlargement.

Being satisfied with the salary ${ }^{4}$ decreases the willingness to emigrate. Note, however, that the latter variable is an interaction between employment and satisfaction with the salary. When estimating the regressions without it, being unemployed becomes significant and positive in the EU10 after the enlargement. This suggests that, in 2005, unemployed have no significantly different intentions to emigrate relative to white-collar employees who are not satisfied with their salary. However, relative to white-collar employees in general, unemployed have a higher willingness to move. Finally, there is an interesting change in gender and family characteristics. While, before enlargement, the willingness to emigrate of women and individuals with children was not statistically significant, after enlargement it is and they are less willing to move than men and individuals without children. Being alone (single, divorced, separated or widowed) is also significantly rising the mobility intentions after enlargement. Coefficients on country dummies (not reported here) show that while before enlargement the largest positive effect for intentions to move abroad (relative to Slovenia) was in Lithuania, after the enlargement it is in Lithuania, Malta and Estonia. ${ }^{5}$

Regarding the EU15, ${ }^{6}$ the situation is mixed. However, those characteristics that mattered before the enlargement remain significant and have the expected signs after enlargement with the exception of labour market variables. Blue-collar workers, self-employed and the inactive have a lower willingness to move compared to the white-collar workers in 2001, but the correlations become insignificant (at the 5 percent level) in 2005. As in the EU10, the unemployed dummy is insignificant, while satisfaction with the salary is negative and significant. Now, however, the unemployment status remains insignificant even in the absence of the satisfaction dummy. The largest intentions to emigrate relative to Germany are in the United Kingdom and Sweden in 2005 and in the United Kingdom and Luxembourg in 2001. That may also capture the intentions of immigrants to return home, although we control for previous migration experience.

Finally, comparing old and new member states before and after the enlargement yields interesting results. Before the enlargement, females, individuals with children, blue-collar workers and self-employed had lower emigration intentions in the EU15, but not in the EU10. After the enlargement, there are no qualitative differences in the determinants of migration intentions in these two regions.

Regarding regional mobility (see Tables A2 and A3), age, education and home ownership yield expected results for both EU10 and EU15 and both before and after the enlargement. Bluecollar workers in 2005 had a lower willingness to move within and across regions in the EU10 and across regions in the EU15, while inactive had a lower intentions to move across regions in the EU15. Individuals living in small towns in EU10 countries had higher intentions to move to another regions both before and after the enlargement. Satisfaction with the salary, in general, affects negatively within-country mobility intentions in the EU15 (with the exception of within-region move in 2001), and in the EU10 it is significant only for the cross-regional mobility in 2005.

\footnotetext{
${ }^{4}$ Since this question was asked only for the employed in 2005 and 2001 (in 2002 all individuals were asked if they are satisfied with their financial situation), we imposed it equal to zero for those not employed in all years. We have also estimated the model without the satisfaction variable and the results were qualitatively very similar.

${ }^{5}$ Regarding occupations, our analysis shows that the majority of those willing to move abroad are skilled manual workers both before and after enlargement, but also middle managers before and employed professionals after enlargement (see Table A6). That may have important implications for designing appropriate immigration policies.

${ }^{6}$ Note that marital status variables were not available in the 2001 data, but we expect that household size and children variables capture that effect. Also, home ownership was missing, however it was not significant (at the 5 percent level) neither in 2005 nor for the EU10 countries.
} 
Different "push" factors may influence emigration decisions from a macro level. (See Zimmermann, 1995b, for a discussion of "push" and "pull” factors of European migration.) Table 4 (see also Tables A4 and A5) provides some evidence." In the EU10, as was expected, the higher GDP per capita, the less willing are individuals to emigrate, but the effect before enlargement is significant only at the 10 percent level. ${ }^{8}$ This seems to be consistent with the catching up process in the new member states when the income differentials between sending and receiving countries become smaller and potential emigration is negatively affected. In the EU15, the larger is GDP per capita, the larger are the intentions to emigrate in $2001 .^{9}$ Potential explanations may include tax considerations or return intentions. (Note, however, that we control for individual characteristics as mentioned above.) The unemployment rate does not significantly affect the emigration intentions when considered at a 5\% level.

Selection effects are an important issue for the analysis of migration (Roy, 1951, Borjas, 1987, Chiswick, 1999). Although, we do not attempt to rigorously test selectivity here, we have experimented with adding the Gini coefficient into the regressions for the EU10 countries for 2005 (see Liebig and Sousa-Poza, 2004). Note, however, that the data on the potential destination countries, and thus on the relative inequality is not available. The Gini coefficient is highly significant and positive implying that higher inequality is associated with higher willingness to emigrate (see Table A5). ${ }^{10}$ Note also the existence of positive self-selection on observables as emigration intentions increase with the years of schooling. This is consistent with Liebig and SousaPoza (2004) where migration intentions data are used and positive self-selection is suggested, as well as with Chiswick (1999) and Chiquiar and Hanson (2005) that show that positive self-selection may occur in countries with high inequality if migration costs are lower for the highly skilled. We did not find evidence, however, of the attenuation of this effect, since the interaction between education and Gini index was not significant. Note also that the GDP per capita variable becomes insignificant once the Gini index is added into the regressions.

Although not a complete test of the Roy-Borjas model, these findings are interesting on their own. Since the majority of the EU10 countries are former socialist economies, in which income distribution was more egalitarian, higher willingness to emigrate in countries with higher inequality may be important for policy-makers. On the other hand, if these results are able to capture the potential self-selection effects, they have important policy implications also for the receiving countries. As pointed out in Liebig and Sousa-Poza (2004), receiving countries with relatively more equal income distribution, such as Sweden or Germany, may not attract more low skilled people, but may experience skilled immigration, though the positive selectivity will be more pronounced in countries with a higher inequality, such as the UK (p. 141). In addition, Constant and Zimmermann (2005) provide evidence that Germany and Denmark could benefit from more pro-active recruitment and integration policies targeted at immigrants with strong economic performance, such as selection of skilled migrants.

\footnotetext{
${ }^{7}$ We have also estimated a binary choice model for the intentions to emigrate with macroeconomic variables and the results were essentially the same.

${ }^{8}$ We have also experimented with GDP per capita squared to test the migration "hump" hypothesis (see Hatton and Williamson, 2002). However, for the EU10 both GDP and GDP squared were insignificant.

${ }^{9}$ For the EU15 both GDP and GDP squared were insignificant in the 2005 regressions, and we found evidence for an inverse U-shape relation for 2001. However, other reasons than liquidity constraints mentioned in the literature are likely to drive that relation.

${ }^{10}$ In Fouarge and Ester (2007), the Gini coefficient was insignificant in the pooled regression for EU25 in 2005.
} 


\section{SCALE OF POST-ENLARGEMENT MIGRATION: AN ANALYSIS OF THE ATTITUDES IN EU25}

This section of the paper is devoted to the analysis of perceptions about the scale of migration after the 2004 enlargement. We know from Section III that actual migration flows have increased more than was expected in the UK and Ireland while the inflow was less than expected in Sweden. These three countries have opened up their labour markets immediately in 2004 while most other EU countries remained closed due to public concerns about potential mass immigration. What are public perceptions across countries about the actual magnitude of migration in Europe? What factors drive those attitudes? Is there a correlation between these perceptions and actual migration flows? These are the issues we focus on in this section.

We use the 2006 Eurobarometer data and examine the following question:

"According to you, after the last enlargement of the European Union that took place in May 2004, migration flows between the 10 new Member States and the 15 old Member States have been: 1) very important, 2) fairly important, 3) fairly limited, 4) very limited, 5) don't know." 11

We construct a binary dependent variable, which is equal to 1 if a respondent thinks migration flows were very or fairly important, and 0 if she thinks they were limited. ${ }^{12}$ While constructing the sample, we keep individuals between 18 and 64 years old, those with non-missing information and focus on the EU25 countries. Figure 4 shows the distribution of migration perceptions by country for the final sample. Overall, around 65\% of respondents in the EU25 think that post-enlargement migration was "important" (as opposed to "limited") and the figure is slightly larger in the new than in the old member states. There exists a large variation in answers between member states.

Among the EU15 (see panel a of Figure 4), Ireland has the largest proportion of individuals with positive answers (around 95\%), and Sweden has the smallest (around 30\%). Among the EU10, the proportion is the highest in Latvia, Lithuania and Poland. Interestingly, those countries in which immigration from the East or emigration to the West was large (see Section III) seem to report a higher perception of migration and vice versa. This suggests that there exists a potential correlation between actual migration and individual attitudes about its magnitude. Note, however, that these attitudes may originate from at least three different sources - personal migration experience, respondent's level of information and education, and attitudes towards immigration in general. In the regressions below we control for such individual characteristics.

We treat individual answers as indicative about their opinion on the magnitude of migration after the 2004 enlargement. Several factors support that. First, the preceding question asked in the Eurobarometer is whether the value of exports of the EU15 to the new EU10 countries "has been bigger, smaller or equal" to the value of their imports. After having answered this question, respondents are more likely to think about the magnitude of migration than about its impacts. Second, there exists a significant correlation with other questions on the magnitude of migration after the enlargement (whether enlargement increases settlement of workers coming from future member states of the EU and whether enlargement facilitates mobility of people within Europe). Nevertheless, we do acknowledge that respondents may have the impacts of migration in mind.

We expect that the attitudes towards the scale of migration are related to those towards immigration in general. (For studies on the attitudes towards migrants in general see, for instance, Bauer et al., 2000; Gang et al., 2002; Dustmann and Preston, 2006; Mayda, 2006.) The determinants of both are expected to be related. Indeed, immigration attitudes are likely to be an important determinant of actual migration flows as individual preferences affect the demand side of the market through voting and immigration policies (Mayda, 2006).

11 Note that responses in the "don't know" category were treated as missing observations. The proportion of respondents with such answers was $20 \%$.

${ }^{12}$ We have also estimated an ordered probit model using the multiple responses, but report the binary results only since we got no different conclusions. 
Both economic and non-economic factors determine individual attitudes towards immigrants, the scale of immigration, and thus preferences on immigration policy. Both labour market considerations, welfare considerations and racial attitudes matter (Dustmann and Preston, 2007). It is also found that anti-immigration attitudes are higher in regions with a higher concentration of foreigners. (See, for example, Gang et al, 2002 for a study with Eurobarometer data.) Here we do not test this hypothesis. Instead, we analyse whether there exists a correlation between the actual migration flows and individual attitudes towards the scale of migration.

The basic economic model of the effects of immigration postulates that natives who are substitutes to immigrants lose from immigration, while those who are complements gain. The evidence above suggests that immigrants coming from the new member states to the old EU15 selfselect themselves into relatively low-skilled sectors and occupations. We thus expect that highly skilled natives in the EU15 would not perceive immigration from the EU10 as a large-scale event, while the opposite would hold for the low-skilled natives. Indeed, we find that highly educated individuals in the EU15 are less likely to think that migration flows after enlargement were "important", while blue-collar workers are somewhat more likely to think so (see Table 5). On the other hand, better educated individuals are more likely to be better informed about the magnitude of migration in the EU. Finally, it is also possible that answers of less-skilled individuals in may reflect their fears about negative impacts of immigrations and vice versa for highly skilled respondents. Interestingly, we do not find the unemployed variable to be significant. In addition, in the EU10, one additional year of schooling decreases the likelihood to perceive post-enlargement migration as "important" by around 1 percentage point in spite of the higher willingness to move abroad for the highly educated (see Scetion IV).

Left-oriented individuals are less likely to report that migration flows after the enlargement were "important" reflecting most likely pro-immigration attitudes in general. Indeed, this variable is significant only in the EU15. Older respondents are less likely to perceive migration as important in the new member states. This is consistent with the findings in Section IV that actual and potential migrants from EU10 are young. Females are also more likely to think that migration was important reflecting probably a relatively high proportion of female emigrants from the new EU members. ${ }^{13}$

Finally, let us examine the correlation between actual migration flows after the 2004 enlargement and individuals' perceptions about them. Migration flows are defined as follows: We calculated emigration from each of the EU10 countries into each of EU15 countries from the Eurostat immigration flows statistics for the EU15 for 2005. Note, however, that the data is unavailable for Ireland and Greece. For the EU15, we use resident / work permit data from the EU Commission Report (2006), Table A1. Table 6 shows marginal effects from logit regressions, in which we replace the country dummies by the actual migration flows as well as GDP per capita and the unemployment rate. This table clearly shows that there exists a positive relation between actual migration flows after the 2004 enlargement and people’s perceptions about their magnitude, and the association is larger in the new member states.

\section{CONCLUSIONS}

While the rise in migration is a global phenomenon, Europeans have remained fairly immobile. After the 2004 enlargement, migration flows have increased, but the increase on average was limited, although Ireland and the UK were affected most (EU Commission, 2006a). The dynamics of the migration stems from the rising share of non-EU immigrants pointing at a greater need to (i) remove barriers to internal EU mobility (Bonin et al., 2008) and (ii) to better select and integrate

\footnotetext{
${ }^{13}$ We have also experimented with the "satisfaction with financial situation” variable However, it was not significantly different from zero.
} 
non-EU immigrants (Zimmermann, 2005a). Skills shortages combined with demographic challenges call for more mobility, especially of the highly skilled.

The analysis in this paper suggests that in line with human capital theory potential migrants from both EU10 and EU15 continue to be young and better educated. In the EU10, the positive impact of human capital is stronger, but family considerations are likely to become a mobility barrier after the enlargement. It is unlikely that actual labour mobility will increase significantly in Europe. In 2006, the proportion of individuals thinking about "living in another member state in order to work" was around 15\% in the EU10 and 9\% in the EU15. However, the shares of those who "thought of it, but gave up the idea" were around 13\% and $11 \%$, respectively (Eurobarometer 65.1, see Table A8). Since social and cultural barriers are likely to persist, policies aiming at facilitating integration, housing, language skills and early mobility experience are needed.

This study also suggests that there exists a correlation between individual perceptions about the scale of post-enlargement migration and actual migration flows, and that better educated and left-oriented individuals in the EU15 are less likely to perceive these flows as "important". On the other hand, only around 50\% of respondents in the EU15 think that immigrants are needed for working in certain sectors of the economy (Eurobarometer 64.2, see Table A7). Individual attitudes about migration and its scale are important for policy. After accession of Bulgaria and Romania in 2007, only Finland and Sweden have opened up their labour markets for their migrants among the old EU15. These are countries where migration flows after the 2004 enlargement were small, and Sweden has the highest proportion of individuals with the positive answers to the above question. 


\section{REFERENCES}

Anderson, B., Ruhs, M., Rogaly, B., and Spencer, S. (2006), 'Fair Enough? Central and East European Migrants in Low-Wage Employment in the UK', Report published by the Joseph Rowntree Foundation, London.

Ahn, N., de la Rica, S., and Ugidos, A. (1999), 'Willingness to Move and Unemployment Duration in Spain', Economica, 66, 335-57.

Ajzen, I. (1988), Attitudes, Personality, and Behaviour, Open University Press, Milton Keynes.

Alvarez-Plata P., Brücker, H., and Siliverstovs, B. (2003), 'Potential Migration from Central and Eastern Europe into the EU-15 - An Update', Report for the European Commission, Part 1, DG Employment and Social Affairs, Brussels.

Bauer, T., and Zimmermann, K. F. (1997), 'Integrating the East: The Labor Market Effects of Immigration', in S. W. Black (ed.), Europe's Economy Looks East - Implications for Germany and the European Union, Cambridge, Cambridge University Press, 269-306.

Bauer, T., and Zimmermann, K. F. (1998), 'Causes of International Migration: A Survey', in C. Gorter, P. Nijkamp, and J. Poot (eds.), Crossing Borders. Regional and Urban Perspectives on International Migration, Ashgate Publishing Ltd, Aldershot, 95-127.

Bauer, T. K., and Zimmermann, K. F. (1999), 'Assessment of Possible Migration Pressure and its Labour Market Impact Following EU Enlargement to Central and Eastern Europe’, IZA Research Report No.3, Institute for the Study of Labor, Bonn, Germany.

Bauer, T. K., Lofstrom, M., and Zimmermann, K. F. (2000) 'Immigration Policy, Assimilation of Immigrants and Natives' Sentiments Towards Immigrants: Evidence from 12 OECD Countries', Swedish Economic Policy Review, 7, 11-53.

Becker, G. S. (1964), Human Capital, New York, National Bureau of Economic Research.

Bertrand, M., and Mullainathan, S. (2001), 'Do People Mean What They Say? Implications for Subjective Survey Data', The American Economic Review 91 (2), 67-72.

Blanchflower, D. G., Saleheen, J., and Shadforth, C. (2007), 'The Impact of the Recent Migration from Eastern Europe on the UK Economy’, IZA Discussion Paper No. 2615, Institute for the Study of Labor, Bonn, Germany.

Boeri, T., and Brücker, H. (main authors) (2001), 'The Impact of Eastern Enlargement on Employment and Labour Markets in the EU Member States', Report for the European Commission, DG Employment and Social Affairs, Brussels.

Boeri, T., and Brücker, H. (2005), 'Migration, Co-ordination Failures and EU Enlargement', Economic Policy, 20, 629-703.

Boeri, T., Bertola, G., Brucker, H., Coricelli, F., Dolado, J., FitzGerald, J., de la Fuente, A., Garibaldi, P., Hanson, G., Jimeno, J., Portes, R., Saint-Paul, G., and Spilimbergo, A. (2002), Who's Afraid of the Big Enlargement? Centre for Economic Policy Research, London.

Böheim, R., and Taylor, M. (2002), 'Tied Down or Room to Move? Investigating the Relationships Between Housing Tenure, Employment Status and Residential Mobility in Britain', Scottish Journal of Political Economy, 49 (4), 369-92.

Bonifazi, C., and Strozza, S. (2001), ' International Migration in Europe in the Last Fifty Years', in C. Bonifazi, and G. Gesano (eds.), Contributions to International Migration Studies, Rome, IRP-CNR, 33-105.

Bonin, H., Eichhorst, W., Florman, C., Hansen, M. O., Skiöld, L., Stuhler, J., Tatsiramos, K., Thomasen, H., and Zimmermann, K. F. (2008), 'Geographic Mobility in the European Union. Optimising its Economic and Social Benefits', Report for the European Commission, mimeo.

Borjas, G. J. (1987), 'Self-Selection and the Earnings of Immigrants', American Economic Review, 77 (4), 531-53.

Borjas, G. J. (1999), 'The Ecomic Analysis of Immigration', in O. C. Ashenfelter and D. Card (eds.), Handbook of Labor Economics, Volume 3A, Chapter 28, Amsterdam, Elsevier. 
Brenke, K., and Zimmermann, K. F. (2007), 'Zuwanderung aus Mittel- und Osteuropa trotz Arbeitsmarktbarrieren deutlich gestiegen', DIW Wochenbericht, 44, 645-53.

Brücker, H., Epstein, G. S., McCormick, B., Saint-Paul, G., Venturini, A., and Zimmermann, K. F. (2002), 'Managing Migration in the European welfare state', in T. Boeri, G. Hanson and B. McCormick (eds.), Immigration Policy and the Welfare System, Oxford University Press, Oxford.

Burda, M. C. (1993), 'The Determinants of East-West German Migration. Some First Results', European Economic Review, 37, 452-61.

Chiswick, B. R. (1999), 'Are Immigrants Favorably Self-Selected?’, American Economic Review, 89 (2), 181-85.

Constant, A., and Zimmermann, K. F. (2008), 'Measuring Ethnic Identity and Its Impact on Economic Behavior', Journal of the European Economic Association, 6 (2-3), 424-433..

Constant, A., and Zimmermann, K. F. (2005), 'Immigrant Performance and Selective Immigration Policy: A European Perspective', National Institute Economic Review, 194, 94-105.

Constant, A., Gataullina, L., and Zimmermann, K. F. (2006). Ethnosizing Immigrants. IZA Discussion Paper No. 2040. Journal of Economic Behavior and Organization, forthcoming.

Doyle, N., Hughes, G., and Wadensjö, E. (2006), 'Freedom of Movement for Workers from Central and Eastern Europe: Experiences in Ireland and Sweden’, SIEPS Report No. 2006:5.

Drinkwater, S. (2003), 'Go West? Assessing the Willingness to Move from Central and Eastern European Countries’, University of Surrey Discussion Paper No. 05/03.

Dustmann, C. (2003), 'Children and Return Migration', Journal of Population Economics, 16, 81530.

Dustmann, C., Casanova, M., Fertig, M., Preston, I., and Schmidt, C. M. (2003), 'The Impact of EU Enlargement on Migration Flows', UK Home Office Report No. 25/03.

Dustmann, C., and Preston, I. (2006), 'Is Immigration Good or Bad for the Economy? Analysis of Attitudinal Responses', Research in Labor Economics, 24, 3-34.

Dustmann, C., and Preston, I. (2007), 'Racial and Economic Factors in Attitudes to Immigration', The B.E. Journal of Economic Analysis \& Policy, 7 (1) Advances, Article 62.

European Commission (2006a), 'Report on the Functioning of the Transitional Arrangements Set Out in the 2003 Accession Treaty (period 1 May 2004-30 April 2006)', Communication from the Commission, COM (2006) 48 final, 8 February 2006, Brussels.

European Commission (2006b), Employment in Europe, Luxembourg, Office for Official Publications of the European Communities.

Eurostat (2006), Population Statistics, European Communities, Luxembourg.

Epstein, G. S., and Gang, I. N. (2006), 'The Influence of Others on Migration Plans', Review of Development Econmics, 10(4), 652 - 65.

Fassmann, H., and Hintermann, C. (1997), 'Migrationspotential Ostmitteleuropa', ISR Forschungsberichte 15, Institut für Stadt- und Regionalforschung, Vienna.

Fassmann, H., and Münz, R. (eds.) (1994), European Migration in the Late Twentieth Century: Historical Patterns, Actual Trends, and Social Implications, Brookfield (VT), Edward Elgar.

Fertig, M., and Schmidt, C. M. (2001), 'Aggregate-Level Migration Studies As a Tool for Forecasting Future Migration Streams’, in S. Djajic (ed.), International Migration: Trends, Policy and Economic Impact, London/New York.

Fidrmuc, J., and Huber, P. (2007), 'The Willingness to Migrate in the CEECs: Evidence from the Czech Republic', Empirica, 34, 351-69.

Fouarge, D., and Ester, P. (2007a), 'Determinants of Migration Intentions in Europe. Exodus or Bounded Mobility?', Institute for Labour Studies, Tilburg University, mimeo.

Fouarge, D., and Ester, P. (2007b), 'Factors Determining International and Regional Migration in Europe', European Foundation for the Improvement of Living and Working Conditions, Dublin. 
Franzmeyer F., and Brücker, H. (1997), 'Europäische Union, Osterweiterung und Arbeitskräftemigration', DIW Wochenbericht, 64(5), 89-96.

Gang, I. N., Rivera-Batiz, F. L., and Yun, M.-S. (2002), 'Economic Strain, Ethnic Concentration and Attitudes Towards Foreigners in the European Union’, IZA Discussion Paper No. 578, Institute for the Study of Labor, Bonn, Germany.

Gilpin, N., Henty, M., Lemos, S., Portes, J., and Bullen, C. (2006), 'The Impact of Free Movement of Workers from Central and Eastern Europe on the UK Labour Market', Working Paper No. 29, Department of Work and Pensions, London, UK.

Gordon, I., and Molho, I. (1995), 'Duration Dependence In Migration Behaviour: Cumulative Inertia Versus Stochastic Change', Environment and Planning, A 27, 1961-75.

Greenwood, M. J. (1997), 'Internal Migration in Developed Countries', in M.R. Rosenzweig and O. Stark (eds.), The Handbook of Population and Family Economics, Vol. 1B, Amsterdam, North-Holland, 1- 48.

Harris, J. R., and Todaro M. P. (1970), 'Migration, Unemployment and Development: A TwoSector Analysis', The American Economic Review, 60 (1), 126-42.

Hille, H., and Straubhaar, T. (2001), 'The Impact of the EU Enlargement on Migration Movements and Economic Integration: Results of Recent Studies', in OECD (ed.), Migration Policies and EU Enlargement. The Case of Central and Eastern Europe, Paris.

Home Office (2008), Accession Monitoring Report May 2004 - March 2008, UK.

Hughes, G. (2007), 'EU Enlargement and Labour Market Effects of Migration to Ireland from Southern, Central and Eastern Europe', Paper presented at the Second IZA Workshop on EU Enlargement and the Labor Markets, Bonn, Germany.

Jennissen, R., van der Gaag, N., and van Wissen, L. (2006), 'Searching for Similar International Trends Across Countries in Europe', Genus, LXII(2), 37-64.

Krieger, H. (2004), 'Migration Trends in an Enlarged Europe', European Foundation for the Improvement of Living and Working Conditions, Dublin.

Layard, R., Blanchard, O., Dornbusch, R., and Krugman, P. (1992), East-West Migration: The Alternatives, MIT Press, Boston.

Liebig, T., and Sousa-Poza, A. (2004), 'Migration, Self-Selection and Income Inequality: An International Analysis', Kyklos, 57 (1), 125-46.

Manski, C.F. (1990). 'The Use of Intentions Data to Predict Behavior: A Best-Case Analysis', Journal of American Statistical Association, 85, 934-40.

Massey, D.S. (1990), 'Social Structure, Household Strategies, and the Cumulative Causation of Migration', Population Index, 56, 1-26.

Mayda, A. M. (2006), 'Who Is Against Immigration? A Cross-Country Investigation of Individual Attitudes toward Immigrants', Review of Economics and Statistics, 88 (3), 510-30.

Mincer, J. (1978), 'Family Migration Decisions', Journal of Political Economy, 86 (5), 749-73. OECD (2007), International Migration Outlook, SOPEMI Report, Paris.

Roy, A. D. (1951), 'Some Thoughts on the Distribution of Earnings', Oxford Economic Papers, 3, 135-46.

Ruhs, M. (2007), 'Greasing the Wheels of the Flexible Labour Market: East European Labour Immigration in the UK', in J. Smith-Bozek (ed.), Labor Mobility in the European Union: New Members, New Challenges, Washington DC, Center for European Policy Analysis, 4-34.

Ruhs, M., and Martin, P. (2008), 'Numbers vs Rights: Trade-offs and Guest Worker Programs', International Migration Review, 42 (1), 249-65.

Sinn, H-W., Flaig, G., Werding, M., Munz, S., Düll, N., and Hofmann, H. (2001), 'EU-Erweiterung und Arbeitskräftemigration. Wege zu einer schrittweisen Annäherung der Arbeitsmärkte', Ifo Beiträge zur Wirtschaftsforschung No. 2.

Sjaastad, L. A. (1962), 'The Costs and Returns of Human Migration', Journal of Political Economy, 70 (4) Supplement, 80-93. 
Tranaes, T. and Zimmermann, K. F. (2004), (eds.), Migrants, Work, and the Welfare State, University Press of Southern Denmark, Odense.

Wadensjö, E. (2007), 'Migration to Sweden from the new EU Member States', IZA Discussion Paper No. 3190, Institute for the Study of Labor, Bonn, Germany.

Wallace, C. (1998), 'Migration Potential in Central and Eastern Europe’, International Organization for Migration (IOM) Technical Cooperation Centre for Europe and Central Asia.

Zaiceva, A. (2006), 'Reconciling the Estimates of Potential Migration into the Enlarged European Union', IZA Discussion Paper No. 2519, Institute for the Study of Labor, Bonn, Germany.

Zaiceva, A., and Zimmermann, K. F. (2008), 'Migration Flows and Effects after EU Enlargement: Predictions, Potentials and Realities', Institute for the Study of Labor, Bonn, mimeo.

Zimmermann, K. F. (1995a), 'Tackling the European Migration Problem', Journal of Economic Perspectives, 9(2), 45-62.

Zimmermann, K. F. (1995b), 'European Migration: Push and Pull', Proceedings of the World Bank Annual Conference on Development Economics 1994, Supplement to The World Bank Economic Review and The World Bank Research Observer, 313-42.

Zimmermann, K. F. (2005a), 'European Labour Mobility: Challenges and Potentials', De Economist, 153, 425-50.

Zimmermann, K. F. (2005b), (ed.), European Migration: What Do We Know?, Oxford University Press, Oxford/New York.

Zimmermann, K. F., Bonin, H., Fahr, R., and Hinte, H. (2007), Immigration Policy and the Labor Market: The German Experience and Lessons for Europe, Springer, Berlin / Heidelberg. 
Table 1: International migration stock (in \% of total population)

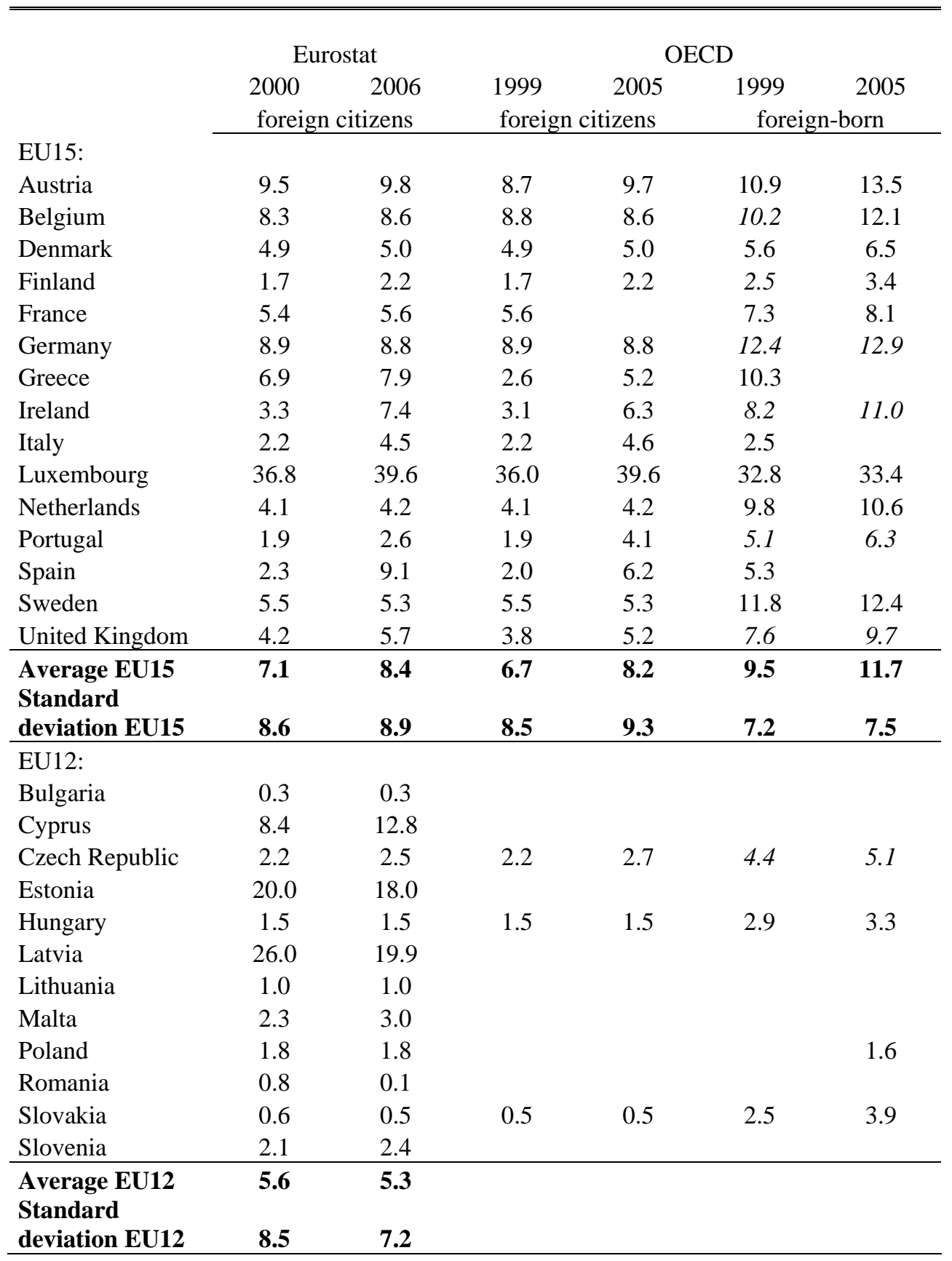

Sources: OECD (2007), Tables A.1.4 and A.1.5 for columns 3-6 and own calculations based on population by citizenship data from the Eurostat online database for columns 1-2 (www.ec.europa.eu/eurostat, June 2008).

Notes: The Eurostat data refer to January 1, while the OECD data refer to December 31 (with several exceptions). In the Eurostat data, instead of 2000 only the following year is available: Greece 2001 (provisional value), France 1999, Lithuania 2001, Poland 2002, Slovakia 2003, Bulgaria 2001, Romania 2002. In the OECD data, instead of 1999 only 2001 is available for Greece, Italy, Slovakia, and Spain; instead of 2005 for Germany it is 2003, for Poland 2002, for Slovakia 2004. Estimated figures by OECD are in italics. The differences between the two data sources may arise also from the different reporting procedures (see OECD, 2007, p.342-343 and 356-357). For the empty slots there are no data available. 
Table 2: Proportion of foreign-born and foreign citizens in European Union countries by region of origin (other EU, non-EU) in \% of total population, 2006

\begin{tabular}{lccccc}
\hline \hline & \multicolumn{2}{c}{ Foreign citizens } & \multicolumn{2}{c}{ Foreign-born } & $\begin{array}{c}\text { Total foreign- } \\
\text { born }\end{array}$ \\
& & & & & \\
EU15: & Other EU & Non-EU & Other EU & Non-EU & \\
\cline { 2 - 4 } & & & & & \\
Belgium & 2.0 & 5.3 & 3.8 & 7.5 & 11.4 \\
Denmark & 6.0 & 2.8 & 6.4 & 6.3 & 12.7 \\
Finland & 0.9 & 2.4 & 1.5 & 3.7 & 5.4 \\
France & 0.6 & 1.0 & 1.1 & 1.7 & 2.8 \\
Germany & 1.8 & 3.3 & 2.7 & 6.8 & 10.3 \\
Greece & 2.1 & 4.5 & - & - & - \\
Ireland & 0.5 & 4.0 & 0.7 & 4.4 & 5.2 \\
Italy & 0.7 & 6.1 & 1.6 & 0.7 & 10.3 \\
Luxembourg & - & - & - & - & 4.2 \\
The Netherlands & 30.4 & 2.8 & 23.8 & 4.3 & 28.2 \\
Portugal & 1.1 & 1.8 & 1.7 & 6.3 & 8.0 \\
Spain & 0.4 & 1.7 & 1.0 & 3.5 & 4.5 \\
Sweden & 0.6 & 3.4 & 1.0 & 4.5 & 5.5 \\
UK & 2.1 & 2.2 & 4.3 & 7.9 & 12.2 \\
& 2.0 & 3.2 & 2.7 & 6.3 & 8.9 \\
EU12: & & & & & \\
Bulgaria & 0.02 & 0.1 & 0.04 & 0.2 & 0.3 \\
Cyprus & 6.0 & 5.1 & 4.9 & 8.6 & 13.6 \\
Czech Republic & 0.3 & 0.3 & 1.4 & 0.6 & 1.9 \\
Estonia & 0.3 & 11.4 & 0.6 & 11.0 & 11.6 \\
Hungary & 0.1 & 0.4 & 0.3 & 1.1 & 1.4 \\
Latvia & 0.1 & $0.9^{3}$ & 1.1 & 11.0 & 12.1 \\
Lithuania & 0.1 & 0.4 & 0.3 & 3.8 & 4.0 \\
Malta & - & - & - & - & - \\
Poland & 0.04 & 0.1 & 0.4 & 0.8 & 1.2 \\
Romania & 0.01 & 0.2 & 0.02 & 0.04 & 0.1 \\
Slovakia & 0.1 & 0.04 & 0.7 & 0.1 & 0.8 \\
Slovenia & 0.02 & 0.3 & 0.6 & 6.0 & 6.6 \\
\hline
\end{tabular}

Source: Authors own tabulations from the EU Labour Force Survey, 2006.

Note: "Other EU" and "Non EU" refer to the EU25 as region of reference.

${ }^{1}$ Data are from 2005.

${ }^{2}$ Neither nationality nor country of birth variables are available.

${ }^{3}$ The number for non-EU citizens is suspiciously low, and similar low numbers are reported in the 2005 Labour Force Survey. This may arise because non-citizens were grouped together with nationals as in Eurostat Population Statistics (2006, p. 65).

${ }^{4}$ This total is based on information on the nationality, citizenship or years of residence variables in the Labour Force Survey and may not be equal to the sum in columns 4 and 5 due to missing information. 
Table 3: Individual determinants of migration abroad intentions in Europe: Marginal effects from the multinomial Logit model

\begin{tabular}{|c|c|c|c|c|}
\hline & \multicolumn{2}{|c|}{ EU10 } & \multicolumn{2}{|c|}{ EU15 } \\
\hline & $\begin{array}{l}\text { Before } \\
\text { enlarg. } \\
2002\end{array}$ & $\begin{array}{c}\text { After } \\
\text { enlarg. } \\
2005\end{array}$ & $\begin{array}{l}\text { Before } \\
\text { enlarg. } \\
2001\end{array}$ & $\begin{array}{c}\text { After } \\
\text { enlarg. } \\
2005\end{array}$ \\
\hline Female & $\begin{array}{c}-0.001 \\
(0.7)\end{array}$ & $\begin{array}{c}-0.011^{* *} \\
(2.2)\end{array}$ & $\begin{array}{l}-0.005^{* * *} \\
(3.4)\end{array}$ & $\begin{array}{c}-0.013 * * * \\
(2.9)\end{array}$ \\
\hline Age & $\begin{array}{c}-0.001^{* * * *} \\
(5.5)\end{array}$ & $\begin{array}{c}-0.002^{* * *} \\
(16.0)\end{array}$ & $\begin{array}{c}-0.001^{* * *} \\
(5.6)\end{array}$ & $\begin{array}{l}-0.001^{* * *} \\
(9.3)\end{array}$ \\
\hline Single & $\begin{array}{c}0.002 \\
(0.5)\end{array}$ & $\begin{array}{c}0.014^{*} \\
(1.7)\end{array}$ & - & $\begin{array}{c}0.015^{* *} \\
(2.2)\end{array}$ \\
\hline $\begin{array}{l}\text { Divorced / separated / } \\
\text { widowed }\end{array}$ & $\begin{array}{c}0.004 \\
(1.0)\end{array}$ & $\begin{array}{l}0.024^{* * *} \\
(6.4)\end{array}$ & - & $\begin{array}{l}0.014^{* * *} \\
\quad(3.0)\end{array}$ \\
\hline Years of schooling & $\begin{array}{l}0.001^{* *} \\
(2.3)\end{array}$ & $\begin{array}{c}0.003^{* * *} \\
(3.9)\end{array}$ & $\begin{array}{c}0.001^{* * *} \\
(3.1)\end{array}$ & $\begin{array}{c}0.002^{* * *} \\
(5.6)\end{array}$ \\
\hline Blue-collar & $\begin{array}{c}-0.003 \\
(1.3)\end{array}$ & $\begin{array}{l}0.002 \\
(0.3)\end{array}$ & $\begin{array}{c}-0.005^{* *} \\
(2.0)\end{array}$ & $\begin{array}{c}-0.007^{*} \\
(1.8)\end{array}$ \\
\hline Self-employed & $\begin{array}{c}0.001 \\
(0.3)\end{array}$ & $\begin{array}{c}0.002 \\
(0.4)\end{array}$ & $\begin{array}{l}-0.006 * * * \\
(2.9)\end{array}$ & $\begin{array}{c}0.016^{*} \\
(1.8)\end{array}$ \\
\hline Unemployed & $\begin{array}{l}0.006 \\
(1.5)\end{array}$ & $\begin{array}{c}0.017 * \\
(1.6)\end{array}$ & $\begin{array}{c}0.004 \\
(0.6)\end{array}$ & $\begin{array}{c}-0.002 \\
(0.4)\end{array}$ \\
\hline Inactive & $\begin{array}{c}-0.005^{* *} \\
(2.2)\end{array}$ & $\begin{array}{l}0.016 \\
(1.2)\end{array}$ & $\begin{array}{c}-0.008 * * \\
(2.2)\end{array}$ & $\begin{array}{c}-0.001 \\
(0.2)\end{array}$ \\
\hline Homeowner & $\begin{array}{c}-0.002 \\
(0.8)\end{array}$ & $\begin{array}{c}-0.009 \\
(1.4)\end{array}$ & - & $\begin{array}{c}-0.011^{*} \\
(1.9)\end{array}$ \\
\hline Rural & $\begin{array}{l}-0.012^{* * * *} \\
(5.5)\end{array}$ & $\begin{array}{l}-0.027^{* * * *} \\
(6.0)\end{array}$ & $\begin{array}{l}-0.006^{* * * *} \\
(3.5)\end{array}$ & $\begin{array}{c}-0.012 * * * \\
(3.4)\end{array}$ \\
\hline Small town & $\begin{array}{c}-0.008^{* * *} \\
(4.1)\end{array}$ & $\begin{array}{c}-0.012^{* * * *} \\
(2.8)\end{array}$ & $\begin{array}{c}-0.005 * \\
(1.9)\end{array}$ & $\begin{array}{c}-0.009 * * \\
(2.3)\end{array}$ \\
\hline Have children & $\begin{array}{c}-0.006 \\
(1.3)\end{array}$ & $\begin{array}{c}-0.016^{* * *} \\
(4.4)\end{array}$ & $\begin{array}{c}-0.016^{* * *} \\
(6.6)\end{array}$ & $\begin{array}{c}-0.020 * * * \\
(5.4)\end{array}$ \\
\hline Household size & $\begin{array}{c}0.0002 \\
(0.3)\end{array}$ & $\begin{array}{c}0.002 \\
(1.4)\end{array}$ & $\begin{array}{l}0.001 \\
(1.03)\end{array}$ & $\begin{array}{c}-0.0001 \\
(0.1)\end{array}$ \\
\hline Moved abroad before & $\begin{array}{c}0.053 * * \\
(2.4)\end{array}$ & $\begin{array}{c}0.099 * * * \\
(4.6)\end{array}$ & $\begin{array}{c}0.087 * * * \\
(4.9)\end{array}$ & $\begin{array}{c}0.077^{* * *} \\
(10.3)\end{array}$ \\
\hline Satisfied with salary & $\begin{array}{c}-0.004^{* *} \\
(2.1)\end{array}$ & $\begin{array}{c}-0.012^{* * *} \\
(3.0)\end{array}$ & $\begin{array}{c}-0.004^{* * *} \\
(2.7)\end{array}$ & $\begin{array}{c}-0.010^{* *} \\
(2.2\end{array}$ \\
\hline Pseudo R2 & 0.14 & 0.16 & 0.13 & 0.13 \\
\hline Observations & 5,021 & 4,748 & 8,081 & 8,627 \\
\hline
\end{tabular}

Source: Authors' estimation based on the data from Eurobarometers 64.1, 54.2 and Central and Eastern Eurobarometer 2002.1.

Notes: The dependent variable in the Logit model takes value one if a respondent replies that in the next five years she intends to move to another city within the same region, it takes value two if she intends to move to another region within the same country, it takes value three if she intends to move to another EU or a non-EU country, and is zero otherwise. The table contains only the estimates for the move abroad. Elasticities are reported that show by how much the change in independent variable changes the dependent variable relative to the reference group of the stayers. (For dummy variables we report a discrete change from 0 to 1.) Only outcome for moving abroad is reported. Country dummies are included in all regressions. Standard errors are adjusted for clustering by country. The absolute values of the z-statistics are reported in parentheses. * significant at $10 \%$; ** significant at 5\%; *** significant at $1 \%$. 
Table 4: Macroeconomic determinants of migration abroad intentions in Europe: Marginal effects from the multinomial Logit model

\begin{tabular}{lcccc}
\hline \hline & \multicolumn{2}{c}{ EU10 } & \multicolumn{2}{c}{ EU15 } \\
& $\begin{array}{c}\text { Before } \\
\text { enlarg. }\end{array}$ & $\begin{array}{c}\text { After } \\
\text { enlarg. }\end{array}$ & $\begin{array}{c}\text { Before } \\
\text { enlarg. }\end{array}$ & $\begin{array}{c}\text { After } \\
\text { enlarg. }\end{array}$ \\
& 2002 & 2005 & 2001 & 2005 \\
\cline { 2 - 5 } GDP per capita & $-0.009^{*}$ & $-0.056^{* * *}$ & $0.005^{* *}$ & -0.001 \\
& $(1.9)$ & $(4.0)$ & $(2.0)$ & $(0.3)$ \\
Unemployment rate & 0.000 & $-0.001^{*}$ & -0.001 & $-0.003^{*}$ \\
& $(0.01)$ & $(1.9)$ & $(0.9)$ & $(1.9)$ \\
Pseudo R2 & 0.13 & 0.14 & 0.11 & 0.10 \\
Observations & 5,021 & 4,748 & 8,081 & 8,627 \\
\hline
\end{tabular}

Source: Authors' estimation based on the data from Eurobarometers 64.1, 54.2 and Central and Eastern Eurobarometer 2002.1.

Notes: See Table 3 for references. The specification is the same with the exception that we replaced the country dummies by macro measures of the GDP per capita in Purchasing Power Standards and the unemployment rate. 
Table 5: Selected determinants of post-enlargement migration perceptions: Marginal effects from the Logit model

\begin{tabular}{lcc}
\hline \hline & EU15 & EU10 \\
\cline { 2 - 3 } Age & $-0.002^{*}$ & $-0.003^{* * *}$ \\
Female & $(1.9)$ & $(2.6)$ \\
& $0.029^{* *}$ & $0.036^{* *}$ \\
Years of schooling & $(2.5)$ & $(2.5)$ \\
& $-0.008^{* * *}$ & $-0.007^{* * *}$ \\
Rural & $(4.0)$ & $(2.9)$ \\
& -0.032 & $-0.049^{* *}$ \\
Left-oriented & $(1.4)$ & $(2.4)$ \\
& $-0.038^{* * *}$ & -0.009 \\
Center-oriented & $(2.8)$ & $(0.4)$ \\
& -0.016 & 0.008 \\
Blue-collar worker & $(0.9)$ & $(0.4)$ \\
& $0.044^{*}$ & 0.003 \\
Unemployed & $(1.7)$ & $(0.1)$ \\
Student & 0.040 & 0.023 \\
& $(1.4)$ & $(0.7)$ \\
Pensioner & $-0.105^{* *}$ & -0.059 \\
& $(2.2)$ & $(1.0)$ \\
House work & $0.036^{*}$ & 0.012 \\
& $(1.6)$ & $(0.3)$ \\
Pseudo R & 0.006 & 0.007 \\
Observations & $(0.2)$ & $(0.2)$ \\
& 0.12 & 0.09 \\
& 8,046 & 4,155 \\
\hline
\end{tabular}

Source: Authors' estimations based on the data from the Eurobarometer 65.2.

Notes: The dependent variable equals to one if a respondent replies that migration flows after 2004 enlargement were "important" and 0 if she replies that they were "limited". Additional controls include marital status, immigrant dummies, household size, and countries fixed effects. Elasticities are reported that show by how much the change in independent variable changes the dependent variable relative to the reference group of the stayers. (For dummy variables we report a discrete change from 0 to 1.) Standard errors are adjusted for clustering by country, the absolute value of the z-statistic is reported in parentheses. ${ }^{*}$ significant at $10 \%$; ** significant at $5 \%$; $* * *$ significant at $1 \%$. 
Table 6: Correlation between migration perception and actual migration flows: Marginal effects from Logit

\begin{tabular}{lcc}
\hline \hline & EU15 & EU10 \\
\cline { 2 - 3 } Migration flows, in \% of w.a. population & $0.207 * * *$ & $0.539 * * *$ \\
& $(6.0)$ & $(2.7)$ \\
GDP per capita & $-0.047 * *$ & -0.023 \\
Unemployment rate & $(2.2)$ & $(1.3)$ \\
& -0.021 & -0.014 \\
Pseudo R & $(1.1)$ & $(1.3)$ \\
Observations & 0.09 & 0.06 \\
\hline
\end{tabular}

Source: Authors' estimations based on the data from the Eurobarometer 65.2.

Notes: The dependent variable equals to one if a respondent replies that migration flows after 2004 enlargement were "important" and 0 if she replies that they were "limited". Migration flows for the EU15 refer to residence/work permits (in percent of destination country's working age population) issued to the EU10 nationals after the 2004 enlargement; for Luxembourg data are missing (see EU Commission, 2006, Table A1). Migration flows for the EU10 are calculated from the Eurostat data on immigration into the respective EU15 countries in 2005 (in percent of sending country's working age population), data for Ireland and Greece are missing, data for Belgium and Italy are from 2003, France and Portugal from 2004. Additional controls include individual characteristics as in Table 5. Standard errors are adjusted for clustering by country, absolute values of z-statistics are reported in parentheses. They are ** significant at $5 \%$ or $* * *$ significant at $1 \%$. Note that the raw (unadjusted) correlation (marginal effect) is $0.473^{* * *}(\mathrm{z}=4.13)$ for the EU10 and $0.134^{* * *}(\mathrm{z}=3.67)$ for the EU15. 
Figure 1: Net migration rates before and after the 2004 enlargement

Austria

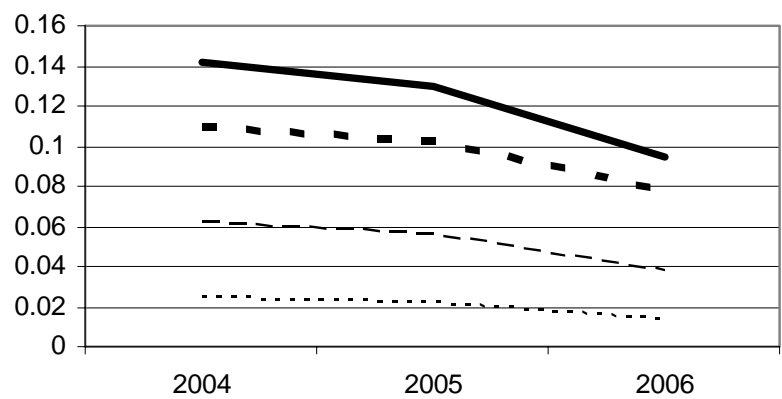

- - - - PL . . . . . RO RO TOTAL EU12 - - ' TOTAL EU10
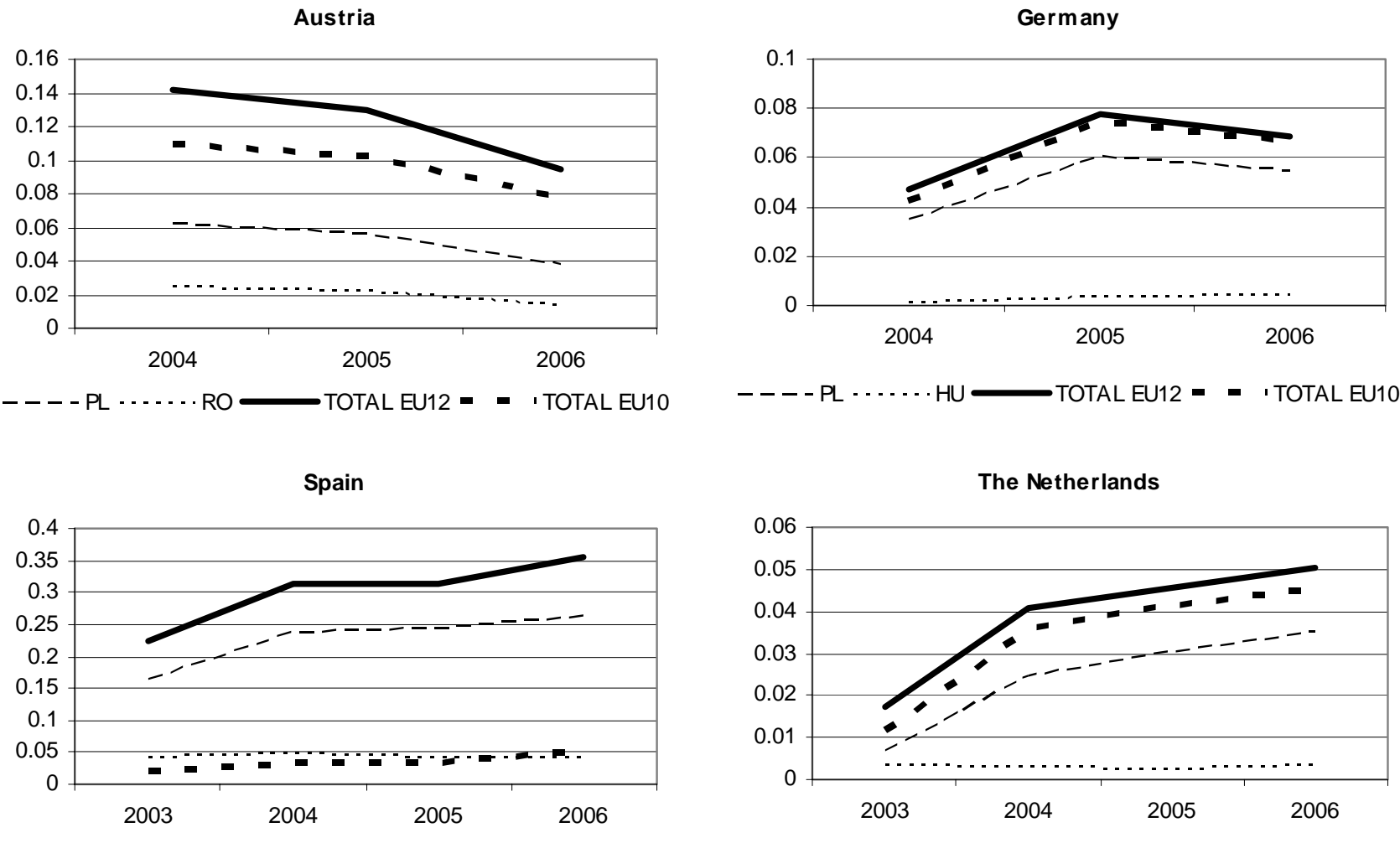

Denmark

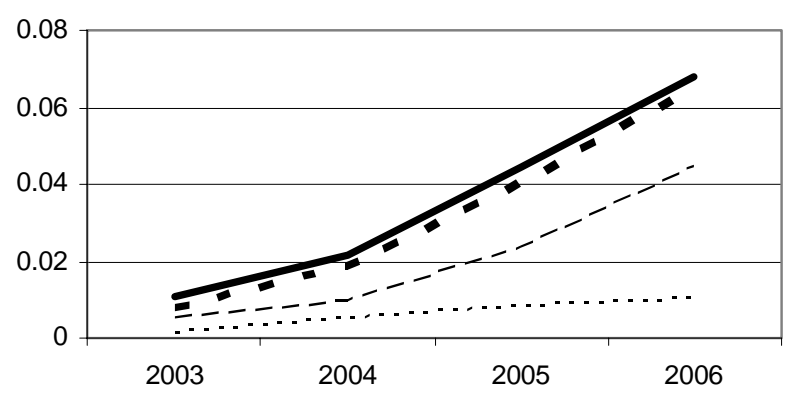

TOTAL EU12 - - TOTAL EU10

Sweden

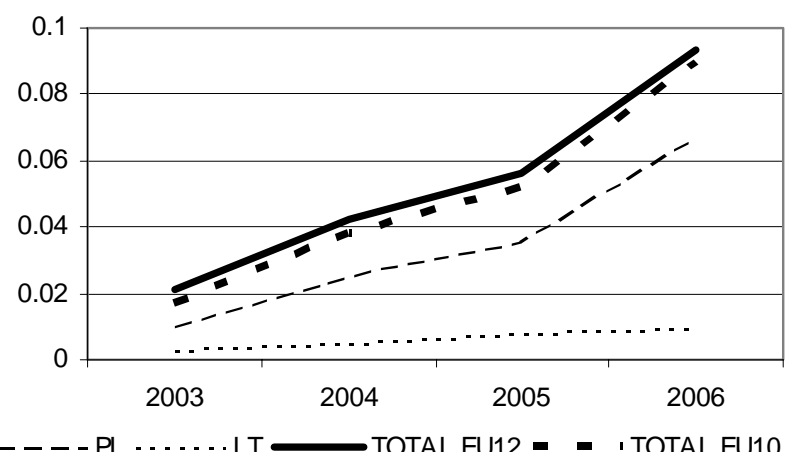

The Netherlands

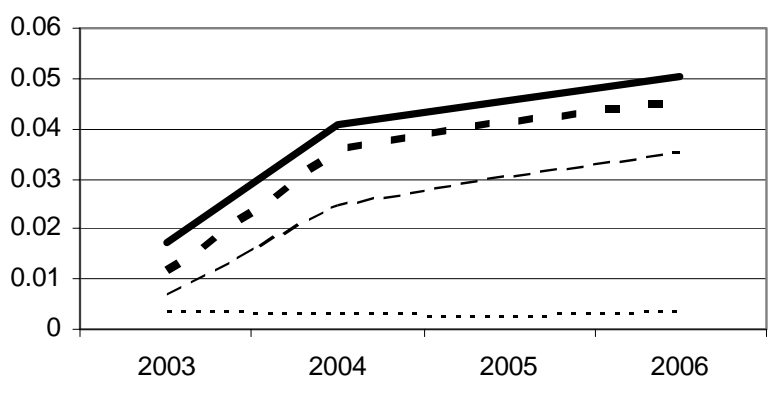

- - - - PL . . . . . RO RO TOTAL EU12 - - ' TOTAL EU10

Finland

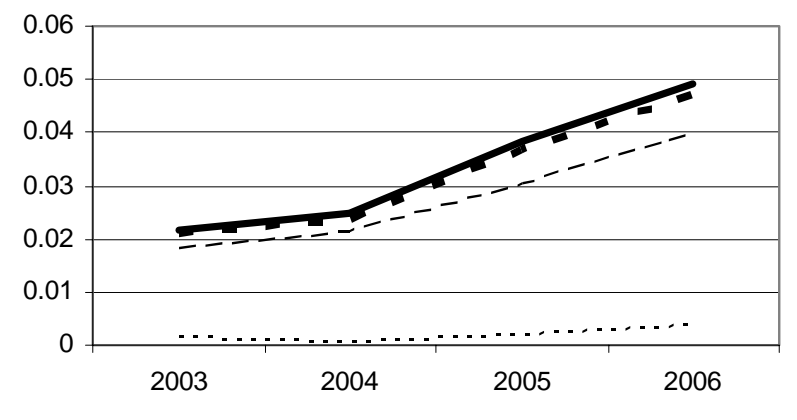

- - - EE . . . . . . PL — TOTAL EU12 - - TOTAL EU10

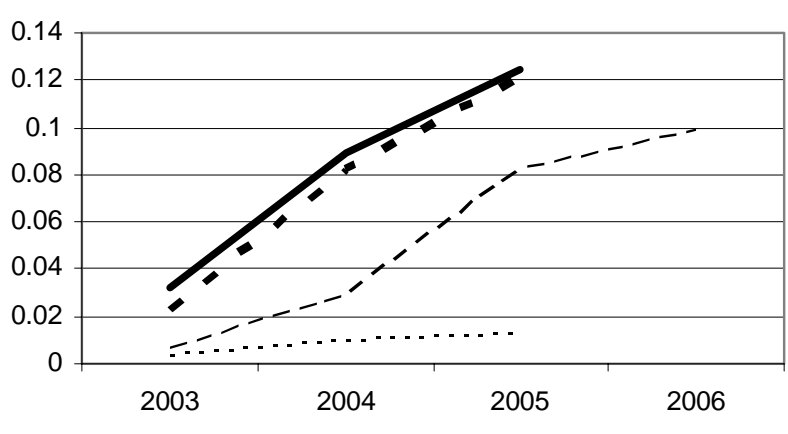

PL . . . . . . SK TOTAL EU12 - - TOTAL EU10

Source: Authors' calculations based on the data from the Eurostat online database ((www.ec.europa.eu/eurostat, June 2008). Notes: The two largest countries of origin from the EU12 together with the total net immigration rates are presented. Net flows are calculated as the difference between immigration and emigration flows for the respective countries of origin and destination divided by the host population size. For the UK gross immigration rates are presented, since data on emigration is missing for many countries and years. 
Figure 2: Applicants to the Worker Registration Scheme, United Kingdom 2004-2007, as percent of population

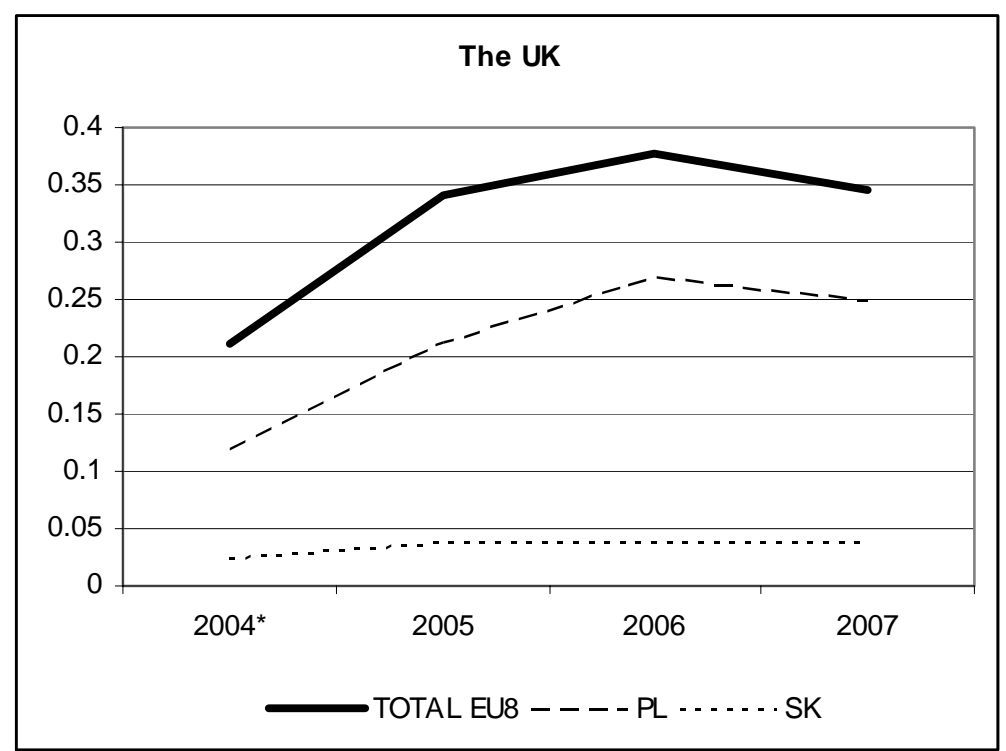

Source: Data are from Home Office (2008), Table 3 and Eurostat..

Notes: Approved applicants and for initial application only.

* 2004 includes May-December. PL refers to Poland and SK to Slovakia, EU8 to the eight countries from Eastern Europe that joined the EU in May 2004 together with Cyprus and Malta. 
Figure 3: Proportion of individuals intending to move abroad

a)

EU15, 2005

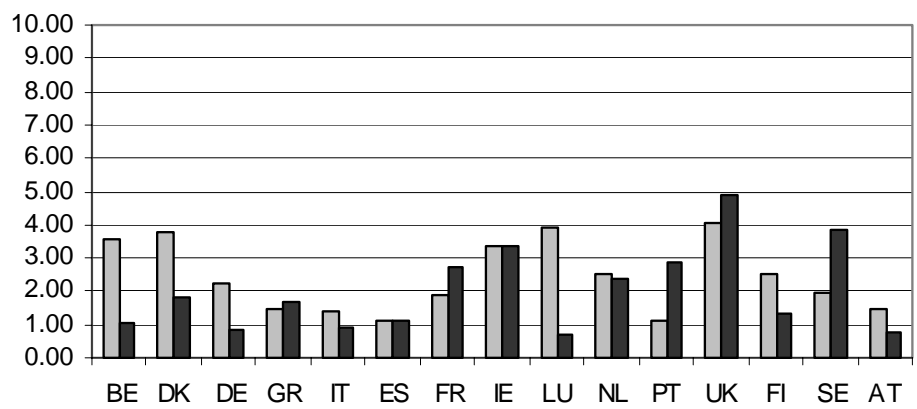

$\square$ to another EU country $\square$ to a non-EU country

c)

EU15, 2001

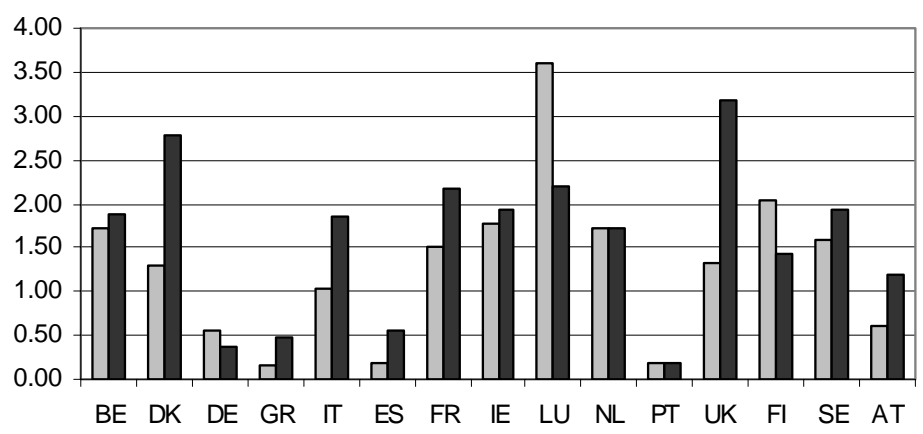

$\square$ to another EU country $\square$ to a non-EU country b)

EU10, 2005

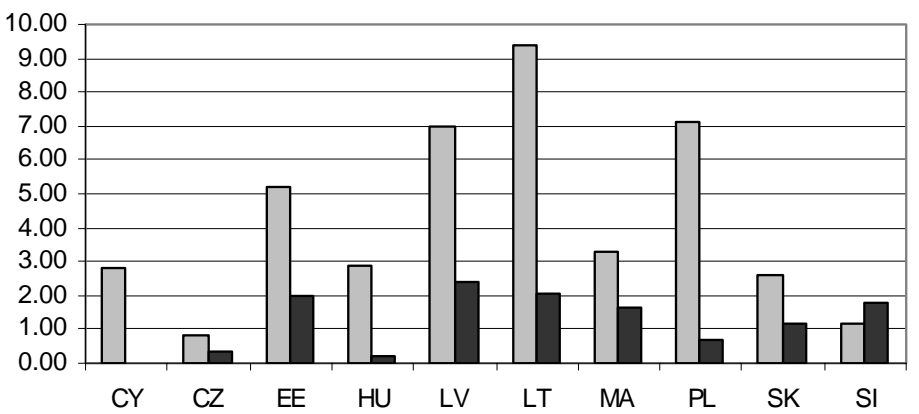

$\square$ to another EU country $\square$ to a non-EU country

d)

EU10, 2002

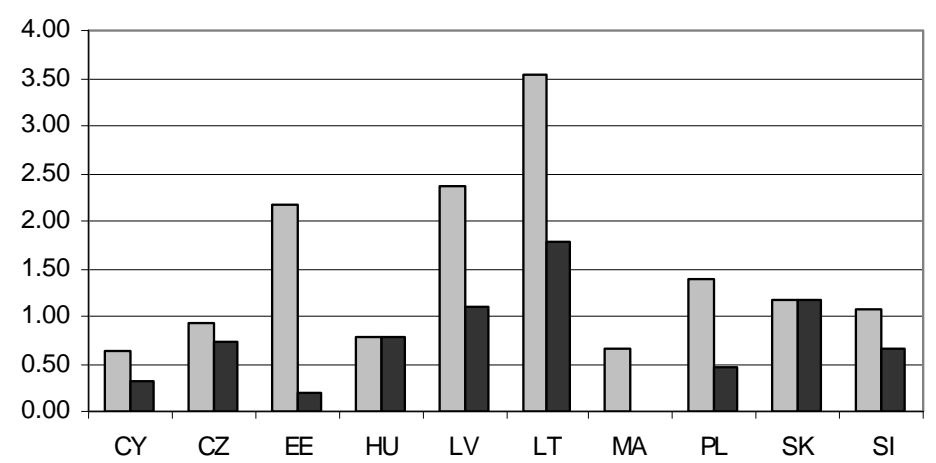

$\square$ to another EU country $\square$ to a non-EU country

Source: Authors' own tabulations from Eurobarometers 64.1, 54.2 and Central and Eastern Eurobarometer 2002.1.

Notes: The sample includes individuals between 18 and 64 years old and excludes pensioners and students. 
Figure 4: Attitudes about post-enlargement migration, 2006:

Proportion of respondents answering migration flows were "important" vs. "limited"

a)

EU15

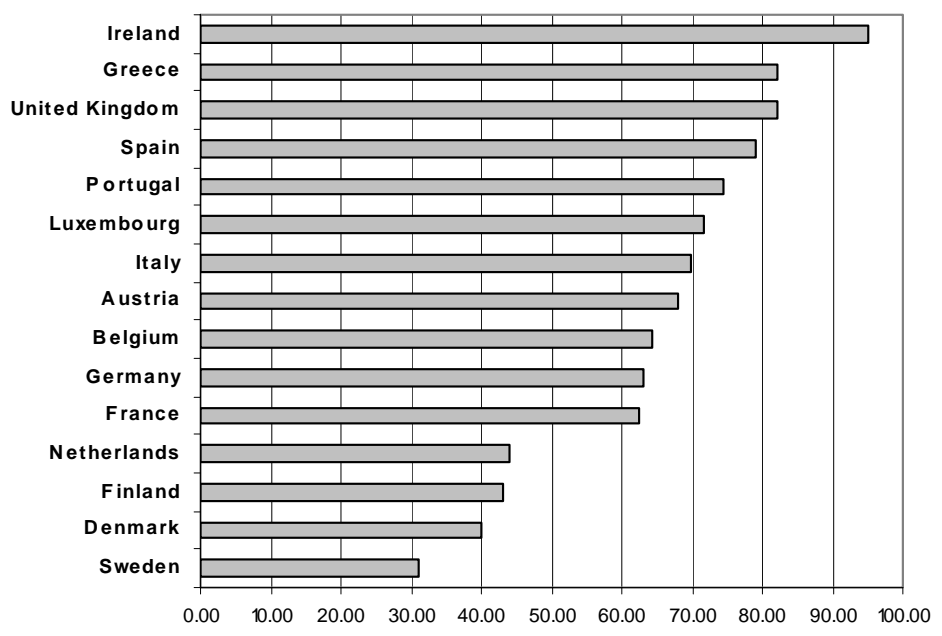

b)

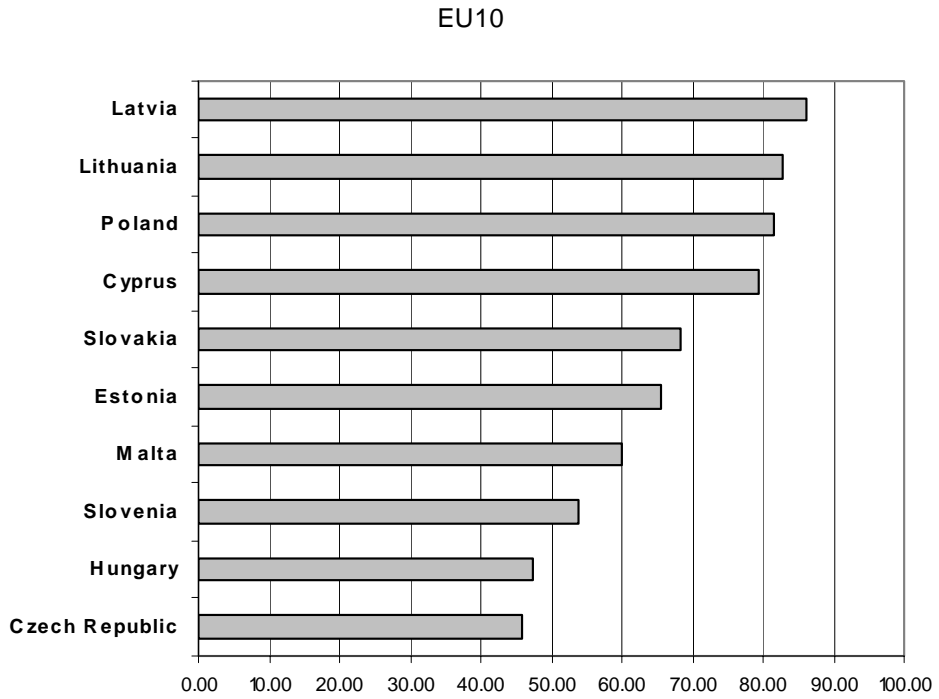

Source: Authors' own tabulations from Eurobarometer 65.2.

Notes: The sample includes all individuals which are 18-64 years old. 


\section{APPENDIX}

\section{Eurobarometers questions}

Eurobarometer EB 54.2, January-February 2001:

Do you think you will move in the next five years? Yes / No / DK

a) Do you intend to move within the same city, town or village in the next five years, or not?

b) And do you intend to move to another city, town or village within the same region, or not?"

c) And do you intend to move to another region within the same country, or not?

d) And do you intend to move to another country within the European Union, or not?

e) And do you intend to live in a country outside the European Union, or not?

f) Are you sure where you will move to, or not?

Candidate Countries Eurobarometer 2002.1, March-April, 2002:

Do you intend to move in the next five years? Yes / No / DK

In the next five years do you intend to...

a) move within the same city, town or village?

b) move to another city, town or village within the same region?

c) move to another region within the same country?

d) move to another country within the Europe?

e) live in a country outside Europe?

Eurobarometer EB 64.1, September-October 2005:

Do you think that in the next five years you are likely to move...?

a) in the same city / town /village?

b) to another city / town / village, but in the same region?

c) to another region, but the same country?

d) to another country in the European Union?

e) to another country outside the European Union?

f) you don't think you will move

g) $\mathrm{DK}$ 
Table A1: Non-national population (in thousands), 1990-2004

\begin{tabular}{|c|c|c|c|c|}
\hline & 1990 & 1995 & 2000 & 2004 \\
\hline \multicolumn{5}{|l|}{ EU15: } \\
\hline Austria & 434 & 677 & 699 & 765 \\
\hline Belgium & 881 & 922 & 897 & 860 \\
\hline Denmark & 151 & 197 & 259 & 271 \\
\hline Finland & 21 & 62 & 88 & 107 \\
\hline France $^{1}$ & 3597 & & 3263 & \\
\hline Germany & 4846 & 7118 & 7336 & 7342 \\
\hline Greece & & & 761 & 891 \\
\hline Ireland & 81 & 96 & 127 & 215 \\
\hline Italy & & 685 & 1271 & 1990 \\
\hline Luxembourg & 109 & 133 & 159 & 175 \\
\hline Netherlands & 642 & 757 & 652 & 702 \\
\hline Portugal & 101 & 157 & 191 & $239^{2}$ \\
\hline Spain & 398 & 461 & 924 & 2772 \\
\hline Sweden & 456 & 537 & 487 & 476 \\
\hline United Kingdom & 2416 & & 2460 & 2941 \\
\hline \multicolumn{5}{|l|}{ EU12: } \\
\hline Bulgaria & & & $26^{3}$ & \\
\hline Cyprus & & 37 & 58 & $65^{2}$ \\
\hline Czech Republic & & & 239 & 195 \\
\hline Estonia & & & 274 & \\
\hline Hungary & & 138 & 153 & 130 \\
\hline Latvia $^{4}$ & & & 25 & 33 \\
\hline Lithuania & & & $34^{3}$ & \\
\hline Malta & 6 & 7 & 9 & 11 \\
\hline Poland & & & $700^{5}$ & \\
\hline Romania & & & & 26 \\
\hline Slovakia & & & & 30 \\
\hline Slovenia & & 48 & 43 & 45 \\
\hline
\end{tabular}

Source: Eurostat (2006), Table C-10, p. 65.

Notes: ${ }^{1}$ Census results 1990 and 1999; ${ }^{2}$ data are from 2003;

${ }^{3}$ Census results 2001; ${ }^{4}$ Including Latvian non-citizens (482 thousand on 1 January 2004); ${ }^{5}$ Census results 2002. 
Table A2: Individual determinants of migration intentions in Europe after enlargement: Marginal effects from the multinomial Logit model

\begin{tabular}{|c|c|c|c|c|c|c|}
\hline & \multicolumn{3}{|c|}{ EU10, 2005} & \multicolumn{3}{|c|}{ EU15, 2005} \\
\hline & $\begin{array}{l}\text { Move } \\
\text { within the } \\
\text { region }\end{array}$ & $\begin{array}{c}\text { Move to } \\
\text { another } \\
\text { region }\end{array}$ & $\begin{array}{l}\text { Move } \\
\text { abroad }\end{array}$ & $\begin{array}{l}\text { Move } \\
\text { within the } \\
\text { region }\end{array}$ & $\begin{array}{c}\text { Move to } \\
\text { another } \\
\text { region }\end{array}$ & $\begin{array}{l}\text { Move } \\
\text { abroad }\end{array}$ \\
\hline Female & $\begin{array}{c}-0.006 \\
(0.8)\end{array}$ & $\begin{array}{c}-0.003 \\
(0.7)\end{array}$ & $\begin{array}{c}-0.011 * * \\
(2.2)\end{array}$ & $\begin{array}{c}-0.008 \\
(1.1)\end{array}$ & $\begin{array}{c}-0.007 \\
(1.3)\end{array}$ & $\begin{array}{c}-0.013 * * * \\
(2.9)\end{array}$ \\
\hline Age & $\begin{array}{c}-0.008^{* * * *} \\
(23.8)\end{array}$ & $\begin{array}{l}-0.001 * * * \\
(6.5)\end{array}$ & $\begin{array}{c}-0.002^{* * * *} \\
(16.0)\end{array}$ & $\begin{array}{c}-0.007^{* * *} \\
(12.9)\end{array}$ & $\begin{array}{c}-0.002^{* * *} \\
(7.9)\end{array}$ & $\begin{array}{c}-0.001 * * * \\
(9.3)\end{array}$ \\
\hline Single & $\begin{array}{c}0.028 \\
(1.3)\end{array}$ & $\begin{array}{c}0.020 \\
(1.6)\end{array}$ & $\begin{array}{c}0.014^{*} \\
(1.7)\end{array}$ & $\begin{array}{c}0.044^{* *} \\
(2.2)\end{array}$ & $\begin{array}{c}0.010 \\
(1.2)\end{array}$ & $\begin{array}{l}0.015^{* *} \\
(2.2)\end{array}$ \\
\hline $\begin{array}{l}\text { Divorced / separated / } \\
\text { widowed }\end{array}$ & $\begin{array}{c}0.064 \\
(7.0)\end{array}$ & $\begin{array}{l}0.018 * * * \\
(2.7)\end{array}$ & $\begin{array}{l}0.024^{* * *} \\
\quad(6.4)\end{array}$ & $\begin{array}{l}0.064 \\
(3.9)\end{array}$ & $\begin{array}{c}0.012 \\
(1.6)\end{array}$ & $\begin{array}{l}0.014^{* * *} \\
\quad(3.0)\end{array}$ \\
\hline Years of schooling & $\begin{array}{l}0.004^{* *} \\
(2.0)\end{array}$ & $\begin{array}{c}0.002^{*} \\
(1.7)\end{array}$ & $\begin{array}{l}0.003^{* * *} \\
(3.9)\end{array}$ & $\begin{array}{l}0.003^{* * *} \\
(5.1)\end{array}$ & $\begin{array}{l}0.002 * * * \\
(3.2)\end{array}$ & $\begin{array}{c}0.002^{* * *} \\
(5.6)\end{array}$ \\
\hline Blue-collar & $\begin{array}{c}-0.020 * * \\
(2.3)\end{array}$ & $\begin{array}{l}-0.010^{* *} \\
(2.4)\end{array}$ & $\begin{array}{c}0.002 \\
(0.3)\end{array}$ & $\begin{array}{c}-0.018^{*} \\
(1.9)\end{array}$ & $\begin{array}{l}-0.022^{* * *} \\
\quad(3.8)\end{array}$ & $\begin{array}{c}-0.007^{*} \\
(1.8)\end{array}$ \\
\hline Self-employed & $\begin{array}{c}-0.022 \\
(1.4)\end{array}$ & $\begin{array}{c}0.001 \\
(0.2)\end{array}$ & $\begin{array}{l}0.002 \\
(0.4)\end{array}$ & $\begin{array}{c}-0.002 \\
(0.1)\end{array}$ & $\begin{array}{c}-0.010 \\
(1.5)\end{array}$ & $\begin{array}{c}0.016^{*} \\
(1.8)\end{array}$ \\
\hline Unemployed & $\begin{array}{c}-0.019 \\
(0.8)\end{array}$ & $\begin{array}{c}-0.001 \\
(0.1)\end{array}$ & $\begin{array}{c}0.017^{*} \\
(1.6)\end{array}$ & $\begin{array}{c}0.030^{*} \\
(1.7)\end{array}$ & $\begin{array}{c}-0.012 \\
(1.5)\end{array}$ & $\begin{array}{c}-0.002 \\
(0.4)\end{array}$ \\
\hline Inactive & $\begin{array}{c}-0.025 * \\
(1.8)\end{array}$ & $\begin{array}{c}0.001 \\
(0.1)\end{array}$ & $\begin{array}{l}0.016 \\
(1.2)\end{array}$ & $\begin{array}{c}-0.041 \\
(2.0)\end{array}$ & $\begin{array}{c}-0.028^{* * *} \\
(4.0)\end{array}$ & $\begin{array}{c}-0.001 \\
(0.2)\end{array}$ \\
\hline Homeowner & $\begin{array}{c}-0.099 * * * \\
(7.5)\end{array}$ & $\begin{array}{c}-0.026^{* * *} \\
(3.3)\end{array}$ & $\begin{array}{c}-0.009 \\
(1.4)\end{array}$ & $\begin{array}{c}-0.128^{* * *} \\
(5.8)\end{array}$ & $\begin{array}{c}-0.044^{* * *} \\
(8.9)\end{array}$ & $\begin{array}{c}-0.011^{*} \\
(1.9)\end{array}$ \\
\hline Rural & $\begin{array}{c}-0.059 * * * \\
(4.1)\end{array}$ & $\begin{array}{c}0.001 \\
(0.2)\end{array}$ & $\begin{array}{c}-0.027 * * * \\
(6.0)\end{array}$ & $\begin{array}{c}-0.041 * * \\
(2.3)\end{array}$ & $\begin{array}{c}0.009 \\
(1.6)\end{array}$ & $\begin{array}{c}-0.012^{* * *} \\
(3.4)\end{array}$ \\
\hline Small town & $\begin{array}{c}-0.001 \\
(0.1)\end{array}$ & $\begin{array}{c}0.014 * * * \\
(2.7)\end{array}$ & $\begin{array}{c}-0.012^{* * * *} \\
(2.8)\end{array}$ & $\begin{array}{c}-0.019 \\
(1.3)\end{array}$ & $\begin{array}{c}0.005 \\
(0.7)\end{array}$ & $\begin{array}{c}-0.009 * * \\
(2.3)\end{array}$ \\
\hline Have children & $\begin{array}{c}-0.020^{*} \\
(1.9)\end{array}$ & $\begin{array}{c}-0.002 \\
(0.3)\end{array}$ & $\begin{array}{c}-0.016^{* * *} \\
(4.4)\end{array}$ & $\begin{array}{c}-0.026^{* *} \\
(2.2)\end{array}$ & $\begin{array}{c}-0.015^{* * *} \\
(3.6)\end{array}$ & $\begin{array}{c}-0.020 * * * \\
(5.4)\end{array}$ \\
\hline Household size & $\begin{array}{c}0.002 \\
(0.4)\end{array}$ & $\begin{array}{c}-0.001 \\
(0.6)\end{array}$ & $\begin{array}{c}0.002 \\
(1.4)\end{array}$ & $\begin{array}{c}0.004 \\
(0.8)\end{array}$ & $\begin{array}{c}-0.001 \\
(0.7)\end{array}$ & $\begin{array}{c}-0.0001 \\
(0.1)\end{array}$ \\
\hline Moved abroad before & $\begin{array}{c}-0.059 * * * \\
(6.2)\end{array}$ & $\begin{array}{c}0.010 \\
(0.7)\end{array}$ & $\begin{array}{c}0.099 * * * \\
(4.6)\end{array}$ & $\begin{array}{c}-0.037 * * * \\
(2.6)\end{array}$ & $\begin{array}{c}0.012 \\
(1.3)\end{array}$ & $\begin{array}{c}0.077 * * * \\
(10.3)\end{array}$ \\
\hline Satisfied with salary & $\begin{array}{c}-0.003 \\
(0.3)\end{array}$ & $\begin{array}{c}-0.008^{* *} \\
(2.4)\end{array}$ & $\begin{array}{c}-0.012^{* * * *} \\
(3.0)\end{array}$ & $\begin{array}{c}-0.025^{* *} \\
(2.4)\end{array}$ & $\begin{array}{c}-0.015^{* *} \\
(2.3)\end{array}$ & $\begin{array}{c}-0.010^{* *} \\
(2.2\end{array}$ \\
\hline $\begin{array}{l}\text { Pseudo R2 } \\
\text { Observations }\end{array}$ & & $\begin{array}{l}0.16 \\
4748\end{array}$ & & & $\begin{array}{r}0.13 \\
8627\end{array}$ & \\
\hline
\end{tabular}

Source: Authors' estimation based on the data from Eurobarometers EB 64.1, 54.2 and Central and Eastern Eurobarometer 2002.1.

Notes: The dependent variable in the Logit model takes value one if a respondent replies that in the next five years she intends to move to another city within the same region, it takes value two if she intends to move to another region within the same country, it takes value three if she intends to move to another EU or a non-EU country, and is zero otherwise. Elasticities are reported that show by how much the change in independent variable changes the dependent variable relative to the reference group of the stayers. (For dummy variables we report a discrete change from 0 to 1.) Country dummies are included in all regressions. Standard errors are adjusted for clustering by country. The absolute value of the z-statistics are reported in parentheses. * significant at $10 \%$; ** significant at $5 \%$; *** significant at $1 \%$. 
Table A3: Individual determinants of migration intentions in Europe before enlargement: Marginal effects from the multinomial Logit model

\begin{tabular}{|c|c|c|c|c|c|c|}
\hline & \multicolumn{3}{|c|}{ EU10, 2002} & \multicolumn{3}{|c|}{ EU15, 2001} \\
\hline & $\begin{array}{l}\text { Move } \\
\text { within the } \\
\text { region }\end{array}$ & $\begin{array}{c}\text { Move to } \\
\text { another } \\
\text { region }\end{array}$ & $\begin{array}{l}\text { Move } \\
\text { abroad }\end{array}$ & $\begin{array}{l}\text { Move } \\
\text { within the } \\
\text { region }\end{array}$ & $\begin{array}{c}\text { Move to } \\
\text { another } \\
\text { region }\end{array}$ & $\begin{array}{l}\text { Move } \\
\text { abroad }\end{array}$ \\
\hline Female & $\begin{array}{c}-0.003 \\
(0.3)\end{array}$ & $\begin{array}{c}-0.002 \\
(0.6)\end{array}$ & $\begin{array}{c}-0.001 \\
(0.7)\end{array}$ & $\begin{array}{c}0.001 \\
(0.1)\end{array}$ & $\begin{array}{c}0.0003 \\
(0.1)\end{array}$ & $\begin{array}{c}-0.005 * * * \\
(3.4)\end{array}$ \\
\hline Age & $\begin{array}{c}-0.006^{* * *} \\
(11.9)\end{array}$ & $\begin{array}{c}-0.001^{* * *} \\
(4.0)\end{array}$ & $\begin{array}{c}-0.001^{* * *} \\
(5.5)\end{array}$ & $\begin{array}{c}-0.007 * * * \\
(18.2)\end{array}$ & $\begin{array}{l}-0.002^{* * *} \\
\quad(17.8)\end{array}$ & $\begin{array}{c}-0.001 * * * \\
\quad(5.6)\end{array}$ \\
\hline Single & $\begin{array}{c}0.017 \\
(0.8)\end{array}$ & $\begin{array}{c}0.019 \\
(1.6)\end{array}$ & $\begin{array}{c}0.002 \\
(0.5)\end{array}$ & - & - & - \\
\hline $\begin{array}{l}\text { Divorced / separated / } \\
\text { widowed }\end{array}$ & $\begin{array}{l}0.039 * * * \\
(4.9)\end{array}$ & $\begin{array}{c}0.010 * * \\
(2.0)\end{array}$ & $\begin{array}{l}0.004 \\
(1.0)\end{array}$ & - & - & - \\
\hline Years of schooling & $\begin{array}{l}0.005^{* * *} \\
(2.9)\end{array}$ & $\begin{array}{c}0.002^{* * *} \\
(4.5)\end{array}$ & $\begin{array}{l}0.001^{* *} \\
(2.3)\end{array}$ & $\begin{array}{c}0.004^{* * *} \\
(5.0)\end{array}$ & $\begin{array}{l}0.001^{* * *} \\
\quad(2.8)\end{array}$ & $\begin{array}{l}0.001^{* * *} \\
\quad(3.1)\end{array}$ \\
\hline Blue-collar & $\begin{array}{c}-0.017 \\
(0.9)\end{array}$ & $\begin{array}{c}-0.007 \\
(1.3)\end{array}$ & $\begin{array}{c}-0.003 \\
(1.3)\end{array}$ & $\begin{array}{c}-0.0002 \\
(0.04)\end{array}$ & $\begin{array}{c}-0.004 \\
(1.0)\end{array}$ & $\begin{array}{c}-0.005^{* *} \\
(2.0)\end{array}$ \\
\hline Self-employed & $\begin{array}{c}0.001 \\
(0.4)\end{array}$ & $\begin{array}{c}-0.0001 \\
(0.03)\end{array}$ & $\begin{array}{c}0.001 \\
(0.3)\end{array}$ & $\begin{array}{c}0.009 \\
(0.8)\end{array}$ & $\begin{array}{c}-0.012^{* *} \\
(2.4)\end{array}$ & $\begin{array}{c}-0.006 * * * \\
(2.9)\end{array}$ \\
\hline Unemployed & $\begin{array}{c}-0.013 \\
(0.6)\end{array}$ & $\begin{array}{c}0.007 \\
(1.2)\end{array}$ & $\begin{array}{c}0.006 \\
(1.5)\end{array}$ & $\begin{array}{c}0.045^{* *} \\
(2.5)\end{array}$ & $\begin{array}{c}0.005 \\
(0.9)\end{array}$ & $\begin{array}{c}0.004 \\
(0.6)\end{array}$ \\
\hline Inactive & $\begin{array}{c}-0.005 \\
(0.2)\end{array}$ & $\begin{array}{c}-0.002 \\
(0.3)\end{array}$ & $\begin{array}{c}-0.005^{* *} \\
(2.2)\end{array}$ & $\begin{array}{l}0.001 \\
(0.04)\end{array}$ & $\begin{array}{c}-0.011^{*} \\
(1.9)\end{array}$ & $\begin{array}{c}-0.008^{* *} \\
(2.2)\end{array}$ \\
\hline Homeowner & $\begin{array}{l}-0.100^{* * *} \\
(5.5)\end{array}$ & $\begin{array}{l}-0.016^{* * *} \\
(3.4)\end{array}$ & $\begin{array}{c}-0.002 \\
(0.8)\end{array}$ & - & - & - \\
\hline Rural & $\begin{array}{c}-0.073^{* * *} \\
(6.2)\end{array}$ & $\begin{array}{c}0.004 \\
(0.9)\end{array}$ & $\begin{array}{c}-0.012^{* * *} \\
(5.5)\end{array}$ & $\begin{array}{c}-0.057 * * * \\
(5.5)\end{array}$ & $\begin{array}{c}0.004 \\
(0.7)\end{array}$ & $\begin{array}{c}-0.006 * * * \\
(3.5)\end{array}$ \\
\hline Small town & $\begin{array}{c}-0.033^{* * * *} \\
(3.0)\end{array}$ & $\begin{array}{c}0.009 * * \\
(2.2)\end{array}$ & $\begin{array}{c}-0.008 * * * \\
(4.1)\end{array}$ & $\begin{array}{c}-0.021 \\
(1.7)\end{array}$ & $\begin{array}{c}0.007 \\
(1.2)\end{array}$ & $\begin{array}{c}-0.005^{*} \\
(1.9)\end{array}$ \\
\hline Have children & $\begin{array}{c}-0.006 \\
(0.3)\end{array}$ & $\begin{array}{c}-0.010 \\
(1.4)\end{array}$ & $\begin{array}{c}-0.006 \\
(1.3)\end{array}$ & $\begin{array}{c}-0.023 * \\
(1.7)\end{array}$ & $\begin{array}{c}-0.011^{* *} \\
(2.1)\end{array}$ & $\begin{array}{c}-0.016 * * * \\
(6.6)\end{array}$ \\
\hline Household size & $\begin{array}{c}0.010^{* * *} \\
(5.5)\end{array}$ & $\begin{array}{c}0.001 \\
(0.3)\end{array}$ & $\begin{array}{c}0.0002 \\
(0.3)\end{array}$ & $\begin{array}{c}-0.001 \\
(0.3)\end{array}$ & $\begin{array}{c}-0.002 \\
(1.2)\end{array}$ & $\begin{array}{l}0.001 \\
(1.03)\end{array}$ \\
\hline Moved abroad before & $\begin{array}{c}-0.006 \\
(0.3)\end{array}$ & $\begin{array}{c}0.030 \\
(0.9)\end{array}$ & $\begin{array}{c}0.053 * * \\
(2.4)\end{array}$ & $\begin{array}{c}0.030 \\
(1.2)\end{array}$ & $\begin{array}{c}0.023^{*} \\
(1.7)\end{array}$ & $\begin{array}{c}0.087 * * * \\
(4.9)\end{array}$ \\
\hline Satisfied with salary & $\begin{array}{l}0.005 \\
(0.4)\end{array}$ & $\begin{array}{c}-0.005 \\
(1.4)\end{array}$ & $\begin{array}{c}-0.004^{* *} \\
(2.1)\end{array}$ & $\begin{array}{c}-0.008 \\
(0.8)\end{array}$ & $\begin{array}{c}-0.015^{* * *} \\
(3.8)\end{array}$ & $\begin{array}{c}-0.004 * * * \\
(2.7)\end{array}$ \\
\hline $\begin{array}{l}\text { Pseudo R2 } \\
\text { Observations }\end{array}$ & & $\begin{array}{l}0.14 \\
5021\end{array}$ & & & $\begin{array}{l}0.13 \\
8081\end{array}$ & \\
\hline
\end{tabular}

Source: Authors' estimation based on the data from Eurobarometers EB 64.1, 54.2 and Central and Eastern Eurobarometer 2002.1.

Notes: The dependent variable in the Logit model takes value one if a respondent replies that in the next five years she intends to move to another city within the same region, it takes value two if she intends to move to another region within the same country, it takes value three if she intends to move to another EU or a non-EU country, and is zero otherwise. Elasticities are reported that show by how much the change in independent variable changes the dependent variable relative to the reference group of the stayers. (For dummy variables we report a discrete change from 0 to 1.) Country dummies are included in all regressions. Standard errors are adjusted for clustering by country. The absolute value of the z-statistics are reported in parentheses. * significant at $10 \%$; ** significant at $5 \%$; *** significant at $1 \%$. 
Table A4: Macroeconomic determinants of migration intentions in Europe: Marginal effects from the multinomial Logit model

\begin{tabular}{|c|c|c|c|c|c|c|}
\hline & \multicolumn{6}{|c|}{ After the enlargement } \\
\hline & \multicolumn{3}{|c|}{ EU10, 2005} & \multicolumn{3}{|c|}{ EU15, 2005} \\
\hline & $\begin{array}{c}\text { Move } \\
\text { within the } \\
\text { region }\end{array}$ & $\begin{array}{l}\text { Move to } \\
\text { another } \\
\text { region }\end{array}$ & $\begin{array}{l}\text { Move } \\
\text { abroad }\end{array}$ & $\begin{array}{l}\text { Move } \\
\text { within the } \\
\text { region }\end{array}$ & $\begin{array}{l}\text { Move to } \\
\text { another } \\
\text { region }\end{array}$ & $\begin{array}{l}\text { Move } \\
\text { abroad }\end{array}$ \\
\hline GDP per capita & $\begin{array}{c}-0.070 * * * \\
(2.7)\end{array}$ & $\begin{array}{c}-0.020 \\
(1.1)\end{array}$ & $\begin{array}{c}-0.056 * * * \\
(4.0)\end{array}$ & $\begin{array}{c}-0.010 \\
(0.5)\end{array}$ & $\begin{array}{c}0.005 \\
(0.8)\end{array}$ & $\begin{array}{c}-0.001 \\
(0.3)\end{array}$ \\
\hline Unemployment rate & $\begin{array}{c}-0.007 * * * \\
(3.8)\end{array}$ & $\begin{array}{c}-0.003^{* *} \\
(2.4)\end{array}$ & $\begin{array}{c}-0.001^{*} \\
(1.9)\end{array}$ & $\begin{array}{c}-0.009 \\
(1.1)\end{array}$ & $\begin{array}{l}0.002 \\
(0.4)\end{array}$ & $\begin{array}{c}-0.003^{*} \\
(1.9)\end{array}$ \\
\hline Pseudo R2 & & 0.14 & & & 0.10 & \\
\hline \multirow[t]{3}{*}{ Observations } & & 4748 & & & 8627 & \\
\hline & \multicolumn{6}{|c|}{ Before the enlargement } \\
\hline & & U10, 2002 & & & $\mathrm{U} 15,2001$ & \\
\hline GDP per capita & $\begin{array}{l}-0.023 \\
(0.053)\end{array}$ & $\begin{array}{c}-0.015 * * \\
(0.007)\end{array}$ & $\begin{array}{l}-0.008 \\
(0.005)\end{array}$ & $\begin{array}{l}-0.017 * \\
(0.011)\end{array}$ & $\begin{array}{c}0.010^{* * *} \\
(0.005)\end{array}$ & $\begin{array}{c}0.005^{* *} \\
(0.003)\end{array}$ \\
\hline Unemployment rate & $\begin{array}{l}-0.003 \\
(0.003)\end{array}$ & $\begin{array}{l}-0.001 * * \\
(0.0004)\end{array}$ & $\begin{array}{c}-0.00004 \\
(0.0003)\end{array}$ & $\begin{array}{l}0.0003 \\
(0.005)\end{array}$ & $\begin{array}{c}0.001 \\
(0.002)\end{array}$ & $\begin{array}{l}-0.001 \\
(0.001)\end{array}$ \\
\hline $\begin{array}{l}\text { Pseudo R2 } \\
\text { Observations }\end{array}$ & & $\begin{array}{l}0.12 \\
5024\end{array}$ & & & $\begin{array}{l}0.11 \\
8081\end{array}$ & \\
\hline
\end{tabular}

Source: Authors' estimation based on the data from Eurobarometers EB 64.1, 54.2 and Central and Eastern Eurobarometer 2002.1.

Notes: The dependent variable in the Logit model takes value one if a respondent replies that in the next five years she intends to move to another city within the same region, it takes value two if she intends to move to another region within the same country, it takes value three if she intends to move to another EU or a non-EU country, and is zero otherwise. Elasticities are reported that show by how much the change in independent variable changes the dependent variable relative to the reference group of the stayers. (For dummy variables we report a discrete change from 0 to 1.) Additional controls include individual characteristics as in Tables A2 and A3, country dummies are excluded. Standard errors are adjusted for clustering by country. The absolute value of the z-statistics are reported in parentheses. * significant at $10 \%$; $* *$ significant at $5 \%$; $* * *$ significant at $1 \%$. 
Table A5: The impact of inequality and education in EU10 after the enlargement: Marginal effects from the multinomial Logit model

\begin{tabular}{lccc}
\hline \hline & $\begin{array}{c}\text { Move } \\
\text { within the } \\
\text { region }\end{array}$ & $\begin{array}{c}\text { Move to } \\
\text { another } \\
\text { region }\end{array}$ & $\begin{array}{c}\text { Move } \\
\text { abroad }\end{array}$ \\
\cline { 2 - 4 } Years of schooling & $0.004^{*}$ & $0.002^{* * *}$ & $0.003^{* * *}$ \\
GDP per capita & $(1.8)$ & $(2.8)$ & $(3.6)$ \\
& -0.022 & 0.014 & -0.014 \\
Unemployment rate & $(0.6)$ & $(0.6)$ & $(0.6)$ \\
Gini index & $-0.006^{* * *}$ & $-0.002^{* *}$ & -0.001 \\
& $(3.4)$ & $(2.3)$ & $(1.0)$ \\
Pseudo R2 & 0.003 & $0.002^{*}$ & $0.003^{* * *}$ \\
Observations & $(1.3)$ & $(1.8)$ & $(2.8)$ \\
\hline
\end{tabular}

Source: Authors' estimation based on the data from Eurobarometer EB 64.1.

Notes: The dependent variable in the Logit model takes value one if a respondent replies that in the next five years she intends to move to another city within the same region, it takes value two if she intends to move to another region within the same country, it takes value three if she intends to move to another EU or a non-EU country, and is zero otherwise. Elasticities are reported that show by how much the change in independent variable changes the dependent variable relative to the reference group of the stayers. (For dummy variables we report a discrete change from 0 to 1.) Additional controls include individual characteristics as in Tables A2 and A3, country dummies are excluded. Standard errors are adjusted for clustering by country. The absolute value of the z-statistics are reported in parentheses. * significant at $10 \%$; $* *$ significant at $5 \%$; ** significant at $1 \%$. 
Table A6: Characteristics of potential emigrants from EU10 and EU15 and of EU10 and EU15 immigrants in the UK

\begin{tabular}{|c|c|c|c|c|c|c|c|c|}
\hline & \multicolumn{4}{|c|}{ EU10 } & \multicolumn{4}{|c|}{ EU15 } \\
\hline & $\begin{array}{l}\text { Intend to move } \\
\text { abroad, } 2002\end{array}$ & $\begin{array}{l}\text { Moved to UK } \\
\text { in 2002-2004 }\end{array}$ & $\begin{array}{l}\text { Intend to move } \\
\text { abroad, } 2005\end{array}$ & $\begin{array}{l}\text { Moved to UK } \\
\text { in 2005-2007 }\end{array}$ & $\begin{array}{l}\text { Intend to move } \\
\text { abroad, } 2001\end{array}$ & $\begin{array}{l}\text { Moved to UK } \\
\text { in 2001-2004 }\end{array}$ & $\begin{array}{l}\text { Intend to move } \\
\text { abroad, } 2005\end{array}$ & $\begin{array}{l}\text { Moved to UK } \\
\text { in 2005-2007 }\end{array}$ \\
\hline Demographic characteristics: & & & & & & & & \\
\hline Female & 0.46 & 0.43 & 0.52 & 0.47 & 0.42 & 0.57 & 0.45 & 0.52 \\
\hline Age & 31.21 & 31.31 & 33.06 & 28.78 & 34.06 & 34.19 & 36.97 & 32.01 \\
\hline Married / cohabiting & 0.55 & 0.51 & 0.53 & 0.30 & - & 0.36 & 0.55 & 0.34 \\
\hline Have children $<16$ y.o. & 0.48 & 0.39 & 0.34 & 0.20 & 0.24 & 0.31 & 0.28 & 0.24 \\
\hline Years of schooling* & 14 & 14 & 14 & 14 & 15 & 15 & 15 & 16 \\
\hline ILO Employment: & & & & & & & & \\
\hline in employment & 0.71 & 0.87 & 0.67 & 0.83 & 0.80 & 0.83 & 0.77 & 0.80 \\
\hline unemployed & 0.26 & 0.03 & 0.22 & 0.08 & 0.15 & 0.03 & 0.14 & 0.07 \\
\hline inactive & 0.03 & 0.10 & 0.11 & 0.09 & 0.05 & 0.14 & 0.09 & 0.13 \\
\hline Self-employed & 0.10 & 0.11 & 0.07 & 0.06 & 0.07 & 0.10 & 0.15 & 0.02 \\
\hline Industry sector (if employed): & & & & & & & & \\
\hline agriculture \& fishing & 0.01 & 0.01 & 0.02 & 0.03 & - & 0.01 & 0.02 & 0 \\
\hline energy \& water & 0.02 & 0.01 & 0.02 & 0 & - & 0 & 0.02 & 0 \\
\hline $\begin{array}{l}\text { Manufacturing } \\
\text { (Eurobarometer 2002: + mining and } \\
\text { quarrying) }\end{array}$ & 0.15 & 0.31 & 0.14 & 0.26 & - & 0.17 & 0.05 & 0.14 \\
\hline Construction & 0.07 & 0.16 & 0.11 & 0.09 & - & 0.05 & 0.07 & 0.03 \\
\hline distribution, hotels \& restaurants & 0.24 & 0.18 & 0.15 & 0.21 & - & 0.23 & 0.15 & 0.27 \\
\hline $\begin{array}{l}\text { (Eurobarometer 2005, 2002: wholesale and } \\
\text { retail trade + hotels and restaurants) }\end{array}$ & & & & & & & & \\
\hline transport \& communication & 0.05 & 0.12 & 0.08 & 0.15 & - & 0.03 & 0.07 & 0.03 \\
\hline banking, finance \& insurance etc & 0.08 & 0.11 & 0.07 & 0.12 & - & 0.19 & 0.09 & 0.35 \\
\hline public admin, educ \& health & 0.22 & 0.07 & 0.23 & 0.09 & - & 0.24 & 0.27 & 0.16 \\
\hline other services & 0.16 & 0.04 & 0.12 & 0.05 & - & 0.06 & 0.07 & 0.03 \\
\hline Eurobarometer 2005: other (spontaneous) & & & 0.07 & & & & 0.18 & \\
\hline $\begin{array}{l}\text { Occupation UK (if employed): } \\
\text { managers and senior officials }\end{array}$ & & 0.04 & & 0.01 & & 0.16 & & 0.16 \\
\hline professional occupations & & 0.04 & & 0.03 & & 0.19 & & 0.26 \\
\hline associate professional and technical & & 0.04 & & 0.05 & & 0.14 & & 0.20 \\
\hline administrative and secretarial & & 0.02 & & 0.03 & & 0.06 & & 0.04 \\
\hline skilled trades occupations & & 0.21 & & 0.13 & & 0.07 & & 0.03 \\
\hline
\end{tabular}


Occupation Eurobarometer:

Self-employed:

Farmer

0

Professional (lawyer, medical practitioner,

accountant, architect etc.)

Owner of a shop, craftsmen, other selfemployed

Business proprietors, owner (full or partner)

of a company

Employed professional (employed doctor,

lawyer, accountant, architect)

General management, director or top

management (managing directors, director

general, other director)

Middle management, other management

(department head, junior manager, teacher,

technician)

Employed position, working mainly at a

desk

Employed position, not at a desk, but

travelling (salesmen, driver etc.)

Employed position, not at a desk, but in a

service job (hospital, restaurant, police,

firemen etc.)

Supervisor

Skilled manual worker

Other (unskilled) manual worker, servant

\subsection{1}

0.04

0.02

0.04

0.14

0.02

0.12

0.13

0.06

0.20

0.05

Claim benefits

(among which child benefits)

Observations ALL

(employed)

\begin{tabular}{cc} 
& 0.27 \\
& 0.74 \\
121 & 208 \\
$(86)$ & $(180)$ \\
\hline
\end{tabular}

Source: Authors own tabulations from the UK Labour Force Survey 2007 first quarter, Eurobarometers EB 64.1, 54.2 and Central and Eastern Eurobarometer 2002.1.

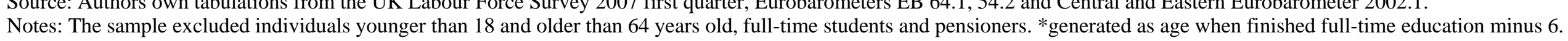


Table A7: Immigration policy. Opinion on the question: "We need immigrants to work in certain sectors of our economy” (in percent)

\begin{tabular}{|c|c|c|c|c|c|c|c|c|c|c|c|c|c|c|c|c|}
\hline & BE & DK & DE & GR & ES & FI & FR & IE & IT & $\mathbf{L U}$ & NL & AT & PT & SE & UK & EU15 \\
\hline & \multicolumn{16}{|c|}{2004} \\
\hline totally agree & 17.30 & 25.87 & 9.22 & 11.50 & 27.16 & 15.60 & 20.18 & 20.90 & 10.02 & 45.06 & 11.97 & 12.21 & 7.70 & 46.40 & 13.46 & 18.34 \\
\hline tend to agree & 28.70 & 32.29 & 24.60 & 19.60 & 36.76 & 37.81 & 37.66 & 40.50 & 38.02 & 32.81 & 22.45 & 30.78 & 29.10 & 34.40 & 36.23 & 31.92 \\
\hline tend to disagree & 30.30 & 22.95 & 28.19 & 23.20 & 17.65 & 24.88 & 21.08 & 17.80 & 27.21 & 13.64 & 30.07 & 27.21 & 35.40 & 10.80 & 19.21 & 23.70 \\
\hline totally disagree & 23.00 & 16.05 & 36.32 & 45.10 & 16.10 & 21.13 & 18.08 & 12.90 & 20.83 & 5.14 & 34.22 & 25.72 & 23.10 & 6.60 & 27.61 & 23.27 \\
\hline \multirow[t]{2}{*}{ don't know } & 0.70 & 2.83 & 1.67 & 0.60 & 2.33 & 0.59 & 3.00 & 7.90 & 3.93 & 3.36 & 1.29 & 4.07 & 4.70 & 1.80 & 3.48 & 2.77 \\
\hline & \multicolumn{16}{|c|}{2005} \\
\hline totally agree & 11.43 & 19.96 & 9.84 & 8.00 & 23.65 & 13.52 & 19.33 & 22.70 & 15.80 & 43.73 & 14.79 & 8.73 & 5.78 & 35.72 & 12.50 & 16.52 \\
\hline tend to agree & 34.47 & 34.79 & 23.21 & 22.20 & 32.61 & 39.01 & 33.99 & 43.31 & 44.10 & 36.67 & 33.05 & 32.94 & 33.20 & 39.79 & 36.67 & 34.27 \\
\hline tend to disagree & 28.32 & 25.10 & 30.57 & 28.50 & 18.33 & 24.22 & 21.61 & 15.36 & 21.30 & 11.37 & 29.88 & 31.47 & 32.40 & 11.52 & 24.47 & 24.27 \\
\hline totally disagree & 24.80 & 15.99 & 34.68 & 41.00 & 16.65 & 22.28 & 21.11 & 10.11 & 13.60 & 6.67 & 19.79 & 22.35 & 22.53 & 11.23 & 20.53 & 21.13 \\
\hline don't know & 0.98 & 4.17 & 1.69 & 0.30 & 8.77 & 0.97 & 3.96 & 8.52 & 5.20 & 1.57 & 2.50 & 4.51 & 6.08 & 1.74 & 5.83 & 3.82 \\
\hline
\end{tabular}

Source: authors’ tabulations from the Eurobarometers EB 64.2 and 62.1. 
Table A8: Past and future of labour migration in Europe.

Answers on the question: “Have you, yourself, ever considered living in another Member State in order to work?” Feb-Mar 2006 (in percent)

\begin{tabular}{|c|c|c|c|c|c|c|c|c|c|c|c|c|c|c|c|c|}
\hline & \multicolumn{16}{|c|}{ EU15 } \\
\hline & $\mathrm{BE}$ & DK & $\mathrm{DE}$ & GR & ES & FI & FR & IE & IT & LU & NL & AT & $\mathrm{PT}$ & $\mathrm{SE}$ & UK & $\begin{array}{c}\text { TOTAL } \\
\text { EU15 }\end{array}$ \\
\hline $\begin{array}{l}\text { yes, you have already done } \\
\text { it }\end{array}$ & 7.75 & 7.58 & 4 & 3.2 & 3.67 & 5.48 & 3.62 & 6.6 & 3.39 & 15.94 & 10.73 & 5.38 & 5.34 & 6.79 & 6.05 & 5.98 \\
\hline $\begin{array}{l}\text { yes, you think of it, but you } \\
\text { haven't decided yet } \\
\text { yes, you have already }\end{array}$ & 9.61 & 12.67 & 10.42 & 6.1 & 4.26 & 11.95 & 7.53 & 7.5 & 7.78 & 5.58 & 6.59 & 8.07 & 5.84 & 11.99 & 9.38 & 8.52 \\
\hline $\begin{array}{l}\text { thought of it, but gave up the } \\
\text { idea } \\
\text { no, you have never thought }\end{array}$ & 12.94 & 14.97 & 12.45 & 5.8 & 6.34 & 12.95 & 10.67 & 7.7 & 11.57 & 7.37 & 16.48 & 13.26 & 11.77 & 13.19 & 9.15 & 11.26 \\
\hline of it & 68.63 & 63.57 & 72.87 & 84.5 & 83.65 & 68.92 & 76.61 & 72.7 & 72.48 & 69.92 & 64.78 & 70.99 & 75.77 & 67.23 & 73.68 & 72.52 \\
\hline don't know & 1.08 & 1.2 & 0.26 & 0.4 & 2.08 & 0.7 & 1.57 & 5.5 & 4.79 & 1.2 & 1.41 & 2.31 & 1.29 & 0.8 & 1.74 & 1.72 \\
\hline
\end{tabular}

\begin{tabular}{|c|c|c|c|c|c|c|c|c|c|c|c|}
\hline & \multicolumn{11}{|c|}{ EU10 } \\
\hline & CY & $\mathrm{CZ}$ & $\mathrm{EE}$ & $\mathrm{HU}$ & LV & LT & MA & $\mathrm{PL}$ & SK & SI & EU10 \\
\hline $\begin{array}{l}\text { yes, you have already done } \\
\text { it }\end{array}$ & 2.76 & 0.97 & 4.48 & 2.58 & 3.64 & 3.69 & 2.4 & 3.3 & 4.58 & 4.17 & 3.34 \\
\hline $\begin{array}{l}\text { yes, you think of it, but you } \\
\text { haven't decided yet } \\
\text { yes, you have already }\end{array}$ & 7.87 & 8.78 & 16.42 & 10.8 & 21.46 & 20.02 & 6.6 & 18 & 16.3 & 12.89 & 14.64 \\
\hline $\begin{array}{l}\text { thought of it, but gave up } \\
\text { the idea } \\
\text { no, you have never thought }\end{array}$ & 4.33 & 13.22 & 12.34 & 11 & 12.3 & 10.56 & 5.2 & 13.1 & 25 & 15.73 & 13.24 \\
\hline of it & 84.06 & 75.1 & 63.98 & 74.53 & 61.71 & 62.75 & 84.4 & 63 & 52.38 & 66.16 & 66.98 \\
\hline don't know & 0.98 & 1.93 & 2.79 & 1.09 & 0.89 & 2.99 & 1.4 & 2.6 & 1.74 & 1.04 & 1.8 \\
\hline
\end{tabular}

Source: authors' tabulations from the Eurobarometer EB 65.1. 